\title{
A comprehensive research in chemical consolidator/stabilizer agents on sand production control
}

\author{
Mohammad Azadi $\operatorname{Tabar}^{1}$ (D) $\cdot$ Hadi Bagherzadeh ${ }^{1} \cdot$ Abbas Shahrabadi $^{1} \cdot$ Sadegh Dahim $^{1}$
}

Received: 15 February 2021 / Accepted: 13 September 2021 / Published online: 22 September 2021

(c) The Author(s) 2021

\begin{abstract}
Sand or fine is a typical product in many processing of oil production from unconsolidated and weakly consolidated formations. High variation of in situ stress, fluid production rate above maximum sand-free rate, and water production are main primary sources of the sand production. Sand production can cause hazardous operational problems to the facilities, pipes, and wellbore. Hence, it is a significant problem that requires to be managed and studied. To minimize the operational impacts of particle migration, chemical consolidators/stabilizers can be utilized to alter surface properties of sand and formation particles. The decreasing zeta potential besides increasing the cohesion between sand and formation particles could result in controlled sand production. However, understanding the mechanism and application of chemical methods to alleviate sand production is not well-discussed. This study presents and discusses chemical consolidator/stabilizer agents, which may be applied for managing sand production in the petroleum industry. This was achieved through a comprehension review of the literature and the application of chemical consolidators/stabilizers in other fields such as bauxite residue (red mud and red sand) control, desert sand, mine reclamation, wind erosion control, unpaved road modification, and enhancement of water retention and soil infiltration properties that are similar to formation sand. Standard experimental methods in various fields, for performance analysis of chemical consolidator/stabilizer agents, are compared and summarized. The consolidation/stabilization mechanisms of various types of chemical consolidator/stabilizer agents are discussed and compared. This review potentially can be used to inhibit blind usage of chemicals and functions as a reference to additional research in sand production control in petroleum engineering. The results are appropriate for extending quantitative approaches for performance evaluation of sand consolidator/stabilizer agents.
\end{abstract}

Keywords Sand production · Chemical consolidator/Stabilizer · Mechanical tests · Unconsolidated reservoir

\section{List of symbols}

UCS unconfined compressive strength, $\mathrm{N} / \mathrm{m}^{2}$

$\sigma_{\max } \quad$ maximum axial force, $N$

A cross-sectional area, $\mathrm{m}^{2}$

$T \quad$ Shear strength, $\mathrm{N} / \mathrm{m}^{2}$

$\sigma \quad$ normal load, $\mathrm{N} / \mathrm{m}^{2}$

$\Phi \quad$ friction angle, Degree

$C$ cohesive stress, $\mathrm{N} / \mathrm{m}^{2}$

$N_{R e} \quad$ Dimensionless Reynolds Number, -

$\rho_{L} \quad$ Density, $\mathrm{kg} / \mathrm{m}^{3}$

$v_{L} \quad$ Superficial Velocity, $\mathrm{m} / \mathrm{s}$

Mohammad Azadi Tabar

m.azaditabar72@gmail.com

$\triangle$ Abbas Shahrabadi

shahrabadia@ripi.ir

1 Petroleum Engineering Division, Research Institute of Petroleum Industry (RIPI), Tehran, Iran

$$
\begin{array}{ll}
K & \text { Absolute permeability, } \mathrm{m}^{2} \\
\mu_{L} & \text { Viscosity, pa s } \\
\mathrm{k}_{\mathrm{rf}} & \text { Relative permeability, } \mathrm{m}^{2}
\end{array}
$$

\section{Introduction}

Although a high rate of oil and gas production is vital to the modern economy, when the rate is higher than a threshold value, it could worsen sand production (Ranjith et al. 2013; Failed 2018; Khamehchi et al. 2015; Khamehchi and Reisi 2015). Increase in fluid production rate is facilitated by reducing bottom hole pressure and in the longer term could result in the two-phase flow (Feng et al. 2012; Li et al. 2011), water coning, condensate accumulation near-wellbore (Jin et al. 2016; Fahes and Firoozabadi 2007; Tang and Firoozabadi 2003), etc. Consequently, sand production from oil and gas reservoirs will be worsen because of increasing 
drag force and in situ stress (Talaghat et al. 2009; Mishra and Ojha 2015, 2016a; Hassani et al. 2017). Sand (or fine) production in oil and gas wells connected with unconsolidated or partially consolidated reservoir rocks consults to the phenomenon in which sand particles are migrated from reservoir to the wellbore by fluids flow during well production. Poorly consolidated reservoirs contain near 70.0 percent of the world's hydrocarbons (Talaghat et al. 2009), hence many oil and gas fields are subjected to sand production. Reports of the volumetric concentration of sand particles in oil pipe systems range from 1.0 to $40.0 \%$ (Liu et al. 2016). A high concentration of sand in the production fluids of oil and gas wells could result in operational problems such as erosion of pipes and separators, instability of production cavities, and loss of well control (Talaghat et al. 2009). The high cost of sand production controlling technology caused a missing of several hundred millions of dollars, yearly (Liu et al. 2016).

Pavement subgrades consolidation/stabilization, unpaved road improvement, desert erosion management, mine reclamation, bauxite residue (red mud and red sand) dust control, and enhancement of soil infiltration and residual saturation of water properties are just some universal application of chemical consolidator/stabilizer (Xu et al. 2018). These references are useful for their application in the sand production control.

The research of chemical consolidator/stabilizer agent on control of dust, formation sand, desert sand, red sand, and red mud initiated in the $20 \mathrm{~s}$ century (Xu et al. 2018), and there are more than 100 invented kinds of chemical consolidator/stabilizer. High compressive strength, high shear strength, and good resistance to erosion caused by the fluid flow are common desirable properties of sand that are treated with consolidator/stabilizer agents. Chemical consolidators/ stabilizers are commonly categorized into inorganic materials (traditional or non-traditional), organic (non-traditional) types. There could be a third type of chemical consolidators/ stabilizers, which is a composite of inorganic material with an organic one (Zang et al. 2015).

The application of different chemical consolidator/stabilizer agents to other types of sand-like particles is typical, while its study and application to control of formation sand production for different kinds of consolidators/stabilizers are rarely discussed in the literature. Furthermore, for an accurate comparison of different chemical agents that are utilized as consolidators/stabilizers, a general procedure (standard laboratory tests) is needed. Usually, in the petroleum industry, the evaluation of consolidators/stabilizers efficiency is limited to porosity, absolute permeability, and unconfined compressive strength tests. Hence, the aims of this study are review the application of chemical consolidator/stabilizer agents to consolidate/stabilize particles which possess similar properties as formation sand, explore the performance of various chemical consolidator/stabilizer, discuss their consolidation/stabilization mechanisms, and finally, investigate their applicability to sand production control in gas and oil reservoirs. To this end, initially, the properties/characteristics of the formation sand are introduced. Then, the commonly used experimental methods, which are utilized in reviewed articles for evaluation of consolidation/stabilization performance, are compared. Then, the classification and properties of the chemical consolidator/stabilizer are introduced. Lastly, the applicability of chemical consolidator/stabilizer agents to formation sand control is discussed, and suggestions for improving the efficiency of consolidator/stabilizer are given. The results are especially useful for petroleum engineers to develop appropriate experimental approaches for the determination of the efficiency of chemical sand production control in both gas and oil wells.

\section{Characteristics of formation sand}

Rocks are usually separated into three major categories of metamorphic, igneous, and sedimentary, based on their geological genesis and processes (Schön 2015). Sedimentary rocks are divided into two groups of (i) Clastics (siliciclastics), (ii) non-clastics (Carbonates and evaporites). Clastics are composed of various silicate particles; carbonates consists mainly of only two minerals of dolomite $\left(\mathrm{CaMg}\left(\mathrm{CO}_{3}\right)_{2}\right)$ and calcite $\left(\mathrm{CaCO}_{3}\right)$ (Schön 2015; Tiab and Donaldson 2015). Carbonate rocks are deposited on-site (mostly marine), while clastics rocks have been transported over long distances (Schön 2015). The clastics rocks based on their size are classified into main groups of sandstone, siltstone, and claystone (from larger to smaller grain size) (Schön 2015). Main elements of sandstone rocks are $\mathrm{SiO}_{2}$ (50-85\%), $\mathrm{Al}_{2} \mathrm{O}_{3}(6-15 \%)$ and $\mathrm{Fe}_{2} \mathrm{O}_{3}(2-7 \%)$ (Tiab and Donaldson 2015; Failed 1983, 2006a). Reservoir rocks are mainly founded in sedimentary rocks and divided up into two types of carbonates and sandstone reservoirs. The rock material of a petroleum reservoir may be composed of unconsolidated and poorly consolidated sand to very hard and dense sandstone, limestone, or dolomite (Ahmed 2006a). Almost $70 \%$ of the world's oil and gas reservoirs are unconsolidated or poorly consolidated sandstone (Zhou and Sun 2016). Hence, sand (fine) migration is a problem mostly in sandstone reservoirs. Framework, matrix, cement, and pores are four major components of sandstone reservoirs. The framework is mainly composed of sand-size or silt-size particles in which major minerals are quartz $\left(\mathrm{SiO}_{2}\right)$ and feldspars (Alkali feldspar $\mathrm{KAlSi}_{3} \mathrm{O}_{8}$ and $\mathrm{NaAlSi}_{3} \mathrm{O}_{8}$ and Plagioclase feldspar $\mathrm{CaAl}_{2} \mathrm{Si}_{2} \mathrm{O}_{8}$ and $\mathrm{NaAlSi}_{3} \mathrm{O}_{8}$ ) (Failed 2006a; Pettijohn et al. 1974). The matrix consists of grains with a size smaller than about $30 \mu \mathrm{m}$, which fill interstitial spaces between the frameworks. The matrix bulk is made of clay minerals (Failed 2006a). The cement bounds particles 
of the framework. Quartz is the most common cement in sandstones, but also calcite and dolomite can be found as the cement in sandstone reservoirs (Failed 2006a).

From a geological point of view, sand are particles with a size smaller than $830 \mu \mathrm{m}$ and larger than $63 \mu \mathrm{m}$ (Schön 2015). It is notable that sand could be subset of the formation sand. Clays define a particle size lower than $2 \mu \mathrm{m}$ (Schön 2015; Pettijohn et al. 1974). Silts define particles with a size between sand and clay. Sandstone, siltstone, and claystone are composed of more than $50 \%$ sand, silt, and clay size particles, respectively (Schön 2015). Clays are aluminosilicates with a sheet structure whose main structure is two kinds of sheets or units. Kaolinite, illite, montmorillonite (smectite), and chlorite are some important clay minerals (Schön 2015). Table 1 summarizes the clay specifications.

Talaghat et al. (2009) used sandstone core composed of quartz, dolomite, calcite and clay, Liu et al. (2016) used bentonite clay with a medium particle size of $5.1 \mu \mathrm{m}$, Hafez et al. (2011) used silicate sand with particle size distribution of 150-250 $\mu \mathrm{m}$, Mishra and Ojha (2016a) used sandstone core, and Li et al. (2017) used quartz with mesh size ranges between 40 and 120 mesh and kaolinites, as sand to investigate sand production control. From previous works on sand control and chemical analysis of formation sand, elements that may be found on sand production and need to be consolidated/stabilized are summarized in Table 2.

Table 1 Some usual elements in sand production (Schön 2015; Tiab and Donaldson 2015; Failed 2006a; Pettijohn et al. 1974)

\begin{tabular}{ll}
\hline Elements & Composition \\
\hline Clays & Described in \\
Quartz & $\mathrm{SiO}_{2}$ \\
k feldspar (microcline) & $\mathrm{KAlSi}_{3} \mathrm{O}_{8}$ \\
Plagioclase feldspar & $\mathrm{CaAl}_{2} \mathrm{Si}_{2} \mathrm{O}_{8}$ \\
& and \\
Calcite & $\mathrm{NaAlSi}_{3} \mathrm{O}_{8}$ \\
Dolomite & $\mathrm{CaCO}_{3}$ \\
\hline
\end{tabular}

Summarizes the particle size of different consolidated/ stabilized materials. It shows that the particle size distribution of sand-like particles is the same as formation sand. Hence, the performed test and utilized chemicals on these materials can be employed on formation sand.

\section{Consolidation quality tests}

More than ten tests have been applied for evaluating the consolidation/stabilization qualities of consolidators/stabilizers in the reviewed articles. The applied methods are zeta potential (Liu et al. 2016), particle size distribution (Liu et al. 2016), sand column (Liu et al. 2016), flow test (Liu et al. 2016), porosity reduction (Bahmani 2017), permeability damage (Bahmani 2017), unconfined compressive strength (Talaghat et al. 2009), shear strength (Liu et al. 2011), penetration resistance (Shulga et al. 2001), flow erosion resistance (Liu et al. 2011), and rainfall erosion resistance (Liu et al. 2011). Initial seven experimental tests mentioned above are usually performed in sand production control (oil and gas industry), lasts five tests are applied in the field of desertification, dust control, etc. This section analyzes the factors and mechanisms utilized in these experimental tests. Evaluation and comparison of the efficiency of chemicals utilized as sand control agents are not possible for petroleum engineers because there is no common standard (experiments) in the petroleum industry ( $\mathrm{Li}$ et al. 2017). Subsequently, based on the experiments conducted for evaluation and comparison of the efficiency of chemical consolidation/stabilization agents of sand-like materials in other fields, we propose some equivalent experimental tests for petroleum engineers.

\section{Zeta potentials}

The difference of electrostatic potential energy between a bulk solution and dispersed particles is defined as zeta potential (Veyskarami and Ghazanfari 2018); the value can be measured by either an electrophoresis-based
Table 2 Comparison of size of reservoir particles and sand like

\begin{tabular}{lll}
\hline Materials & Particle size $(\mu \mathrm{m})$ & Reference \\
\hline Sand & $<830$ & Schön (2015); Pettijohn et al. (1974) \\
Silt & $2-63$ & Schön (2015); Pettijohn et al. (1974) \\
Clay & $<2$ & Schön (2015); Pettijohn et al. (1974) \\
Red sand & $>150$ & Liu et al. (2016) \\
Red mud & $<150$ & Liu et al. (2016) \\
Soil & $10-1000$ & Athukorala (2013) \\
Desert Sand & $0-830$ & Zang et al. (2016) \\
Desert sand & $97 \%$ sand-size particles & Wang et al. (2019a) \\
Red loam sand & $>250$ & Ding et al. (2018a) \\
\hline
\end{tabular}


measurement tool such as Zeta Malvern instrument (Zetasizer Nano ZS90/ ZEN 3600) (Bazyari et al. 2018), or a streaming potential set-up (Dehghan Monfared et al. 2018). It could be utilized to specify the repulsion force between nearby and similarly charged particles in a dispersion of colloids (Liu et al. 2016; Dehghan Monfared et al. 2015). According to classical DLVO theory, there are two forces of the electrical double layer (which is usually repulsive) force and London van der Waals (which is usually attractive) force affecting the colloids aggregation/dispersion (Dehghan Monfared et al. 2015). As the value of the repulsive force is calculated based on the measured zeta potential values, the colloidal stability can be directly interrelated to this parameter. The attraction of sand particles and zeta potential value has an inverse relationship. In other words, a low zeta potential means stronger sand particles attraction than repulsion, while a high zeta potential usually means stability of sand particles and unlikely occurrence of sand particles aggregation (Lu and Gao 2010). Hence, sand particles with low zeta potential electrically tended to aggregate. In this experimental test, usually, zeta potentials of different particles at various concentrations of sand consolidation/stabilization agent and $\mathrm{pH}$ conditions are measured to determine a better consolidator/stabilizer under specific pressure and temperature conditions. The $\mathrm{pH}$ values are determined to find out if $\mathrm{pH}$ could affect the performance of the consolidator/stabilizer. High $\mathrm{pH}$ values along with a variation of other parameters such as consolidator/stabilizer concentration can either explain fines release or trapping in pores (Liu et al. 2016).

Table 3 summarizes surface charges and zeta potentials of some sandstone elements in standard conditions and neutral $\mathrm{pH}$.

\section{Particle size distribution}

The particle size distribution curve, which could be achieved by particle size distribution test, reveals information on the quality of the consolidator/stabilizer agent. Generally, the cumulative percentage smaller than a specific particle size ( $y$-axis) is plotted against the particle size ( $x$-axis). The larger particle size of consolidated sand shows particle aggregation. For example in Fig. 1, the treated sand consist $\sim 80$ percentage of grain size larger than $10 \mu \mathrm{m}$, while for the untreated sand is almost zero. Particle size distributions of sand can be measured using a laser particle size analyzer or a dry sieving setup.

\section{Sand column (static test)}

In this experiment, a test tube (culture tube) in the absence of external forces is usually fulfilled with different amounts of sand and chemical consolidator/stabilizer agents. After treatment time, through the height of the liquid (water) layer of the consolidator/stabilizer agent,

Table 3 Surface charges and zeta potentials of some sandstone elements

\begin{tabular}{|c|c|c|c|c|}
\hline Elements & Main components & Surface charge & Zeta potential $(\mathrm{mV})$ & Reference \\
\hline Bentonite & - & Negative & $-36 \pm 1$ & Liu et al. (2016) \\
\hline Montmorillonite & $\begin{array}{l}60 \% \mathrm{SiO}_{2}, 18 \% \mathrm{Al}_{2} \mathrm{O}_{3}, 4 \% \mathrm{Fe}_{2} \mathrm{O}_{3}, 2 \% \\
\quad \mathrm{MgO},\end{array}$ & Negative & $-36 \pm 1$ & Kaya and Yukselen (2005) \\
\hline Kaolinite & $47 \% \mathrm{SiO}_{2}, 36 \% \mathrm{Al}_{2} \mathrm{O}_{3}$ & Negative & $-35 \pm 1$ & $\begin{array}{l}\text { Kaya and Yukselen (2005; Yukselen-Aksoy } \\
\text { and Kaya (2011) }\end{array}$ \\
\hline Kaolinite & - & Negative & $-41 \pm 1$ & Hussain et al. (1996) \\
\hline Chlorite & - & Negative & $-31 \pm 1$ & Hussain et al. (1996) \\
\hline Illite & - & Negative & $-30 \pm 1$ & Hussain et al. (1996) \\
\hline Nano-silica & $\mathrm{SiO}_{2}$ & Negative & $-42 \pm 1$ & Monfared et al. (2015) \\
\hline Quartz & - & Negative & $-50 \pm 2,-42 \pm 2$ & $\begin{array}{l}\text { Kaya and Yukselen (2005); Yukselen- } \\
\text { Aksoy and Kaya (2011); Failed (2001) }\end{array}$ \\
\hline Pure Quartz & $\mathrm{SiO}_{2}$ & Negative & $-15 \pm 2,-58 \pm 1$ & Vidyadhar et al. (2002); Wang et al. (2018) \\
\hline Pure calcite & $\mathrm{CaCo}_{3}$ & Negative & $-14 \pm 1$ & Monfared et al. (2015) \\
\hline Feldspar & $\begin{array}{l}16 \% \mathrm{Al}, 9 \% \mathrm{Ca}, 3 \% \mathrm{Na}, 1 \% \mathrm{~K}, 22 \% \\
\mathrm{Si}+0.001 \mathrm{M} \mathrm{Na}_{2} \mathrm{~B}_{4} \mathrm{O}_{8}\end{array}$ & Negative & $-32 \pm 1$ & Malysiak et al. (2002) \\
\hline k-feldspar & $\mathrm{KAlSi}_{3} \mathrm{O}_{8}$ & Negative & $-55 \pm 2,-55 \pm 1$ & Failed (2001; Wang et al. 2018) \\
\hline Albite & $\mathrm{NaAlSi}_{3} \mathrm{O}_{8}$ & Negative & $-49 \pm 2,-39 \pm 1$ & Failed (2001); Karagüzel et al. (2005) \\
\hline Albite & $\mathrm{NaAlSi}_{3} \mathrm{O}_{8}+0.1 \mathrm{M} \mathrm{NaCl}$ & Negative & $-43 \pm 1$ & Crundwell (2015) \\
\hline Anorthite & $\mathrm{CaAl}_{2} \mathrm{Si}_{2} \mathrm{O}_{8}+0.001 \mathrm{M} \mathrm{Na}_{2} \mathrm{~B}_{4} \mathrm{O}_{8}$ & Negative & $-28 \pm 2$ & Mhlanga et al. (2012) \\
\hline Anorthite & $\mathrm{CaAl}_{2} \mathrm{Si}_{2} \mathrm{O}_{8}$ & Negative & $-23 \pm 1$ & Abeidu and Kholeif (1976) \\
\hline Dolomite & $31 \% \mathrm{CaO}, 21 \% \mathrm{MgO}$ & Negative & $-1 \pm 1$ & Marouf et al. (2009) \\
\hline
\end{tabular}




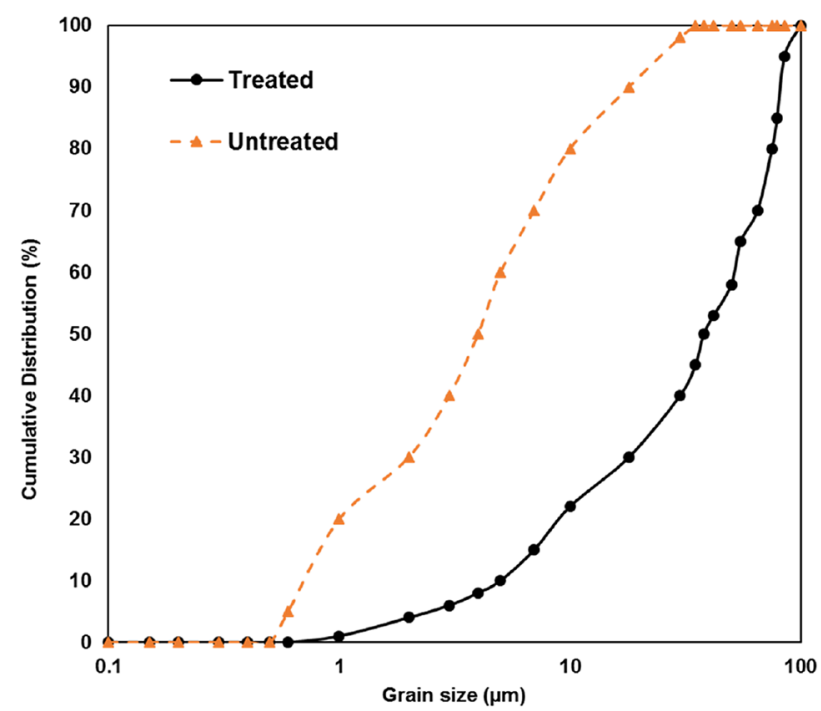

Fig. 1 An example of consolidator/stabilizer influence on the size distribution of sand particles (Liu et al. 2016)

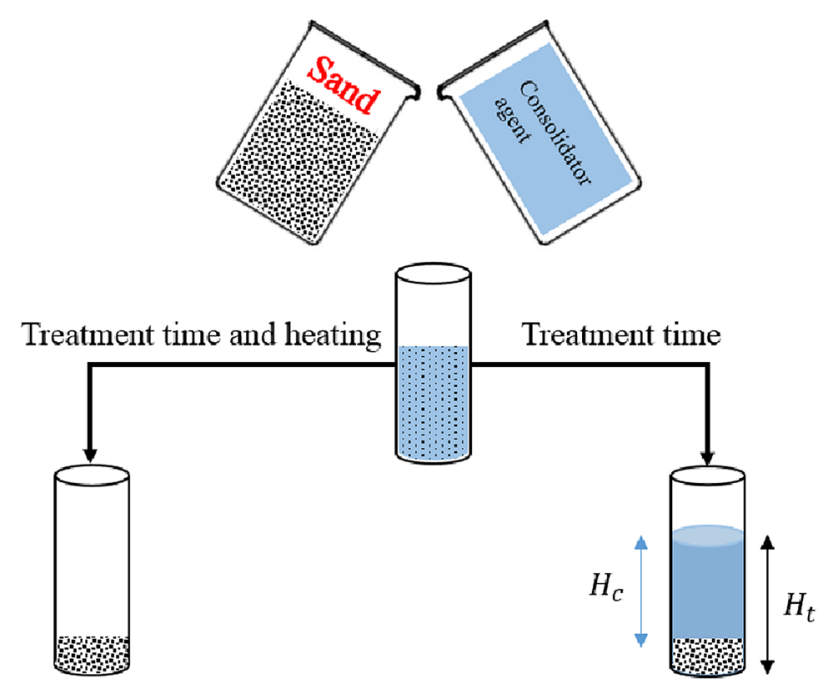

Fig. 2 Sand column test. $H_{\mathrm{C}}$ and $H_{\mathrm{t}}$ are the height of the liquid layer of consolidator/stabilizer agents and total height, respectively

$H_{\mathrm{c}}$, to total height, $H_{\mathrm{t}}$, the flocculability coefficient, $C_{\mathrm{f}}$, is determined. A higher value of $H_{\mathrm{c}} / H_{\mathrm{t}}$, means a better flocculability (see Fig. 2). Flocculation is the coagulation\ agglomeration of suspended colloids (Liu et al. 2016). Also, the sand column test can be conducted in a water bath and heated. After evaporation of consolidator agent, flatness, and cementing strength of the treated sand can be observed by touching consolidated sand. If sand is strongly glued to the test tube, breaking the fragile glass of the test tube is recommended by $\mathrm{Li}$ et al. (2017).

\section{Flow test}

In this experiment, sand packs and cores are used as porous media. The core holders are horizontally placed during the displacement process. There is some different procedure for flow test experiments to investigate the efficiency of sand production control. In some cases, a sand pack is filled with sand, clay, or mineral that is going to be consolidated. Then after saturating and treatment procedure, the injection rate effect on sand production is investigated. In this test, decreasing the mass of produced sand in the flowing fluid is essential ( $\mathrm{Li}$ et al. 2017). In other cases, initially, a sand pack is filled with an unproducible mineral, then saturated with water, and next treated with a consolidator/stabilizer agent. After that, 0.5 pore volume clay suspension is injected into sand pack/core. Finally, water injection is started until the sand breakthrough is observed. In this kind of flow, an increase in the volume of last water injection is important (Liu et al. 2016; Failed 2013). Moreover, the test can be run at residual oil saturation to investigate the oil effect.

\section{Porosity and permeability}

Porosity is defined as the ratio of the volume of voids to the total volume of materials (Ahmed 2006b). Permeability is the capacity of a material to transport fluids (Veyskarami et al. 2016,2017). The reduction in porosity and permeability is the unwanted effect of chemical consolidator/stabilizer agents. So, measuring permeability and porosity reduction as the results of treatment is vital for evaluating the efficiency of consolidator/stabilizer agents. The procedure of porosity and permeability measurements can be found elsewhere (Talaghat et al. 2009; Ahmed 2006a; Dandekar 2013). These tests are rarely reported in other applications of chemical consolidator/stabilizer agents for porosity and permeability retention for sand-like particles. However, the water-retaining property test, in which loss weight of water in fixed sand after a particular time is measured, can shed some valuable information about effective porosity and permeability reduction caused by utilized consolidator/ stabilizer. The result of the water-retaining property test is ordinarily presented as the remaining water content. The following procedure is applied to evaluate the water-retaining capacity in sand (Yang et al. 2007a; Meng et al. 2017; Liu et al. 2012):

- First, a specific weight of treated sand is put into a container (or a container is fulfilled with sand, and then a consolidator/stabilizer agent is sprayed on the sand surface)

- Second, water is poured into the container

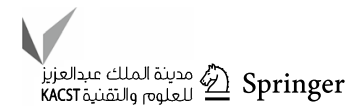


- Third, the water content of the container is determined by taking a small sand sample from the container, ovendrying and determining weight loss as follows:

Gravimetric water content $=($ wet soil weight - dry soil weight)/wet soil weight.

\section{Unconfined compressive strength}

The unconfined compressive strength experiment focuses on the alteration of the structural strength of sand particles after treatment with a chemical consolidator/stabilizer agent (Ding et al. 2018a). Unconfined compressive strength is the maximum axial compressive stress that a cylindrical sample, under unconfined stress, can resist before $15-20 \%$ strain of sample (Xu et al. 2018). The unconfined compressive strength is determined as follows (Mishra and Ojha 2016a):

$\mathrm{UCS}=\frac{\sigma_{\max }}{A}$

where UCS, $\sigma_{\max }$, and $A$ are unconfined compressive strength $\left(\mathrm{N} / \mathrm{m}^{2}\right)$, maximum axial force $(N)$ before failure, and crosssectional area $\left(\mathrm{m}^{2}\right)$ of the cylindrical sample. In the test, the treated sand with the chemical consolidator/stabilizer is fulfilled a cylindrical mold. Based on the American Society for Testing and Materials (Failed 2006b), the minimum radius of the sample is $16.5 \mathrm{~mm}$, and the length ranges from 33 to $82.5 \mathrm{~mm}$.

\section{Shear strength}

The strength of bodies of sand-like particles against an external shear force when it starts structural failure is known as shear strength (Rauch et al. 1993). At the peak stress in which relative motions of sand particles start, failure planes are generated. The efficiency of chemical consolidators/stabilizers agents to improve mechanical strength is determined by measurements of shear strength variation.

Like unconfined compressive strength test, standards of American Society for Testing and Materials describes the procedure of sample preparation (Xu et al. 2018). Generally, for this test, the sample height and width ranges from 20 to $25 \mathrm{~mm}$ and from 60 to $100 \mathrm{~mm}$, respectively (Sivakugan et al. 2011). There are three different methods for shear strength test based on the effect of drainage condition and the consolidation quality, which are known as undrained, consolidated quick, and slow. The link between shear strength $\left(\tau, \mathrm{N} / \mathrm{m}^{2}\right)$ and normal load $\left(\sigma, \mathrm{N} / \mathrm{m}^{2}\right)$ on the failure plane can be defined as follows (Rauch et al. 2002):

$\tau=\sigma \tan \varphi+c$. where $\varphi$ and $c$ are friction angle (or angle of shearing resistance), and cohesive stress (apparent cohesion) $\left(\mathrm{N} / \mathrm{m}^{2}\right)$, respectively. Regarding Eq. (2), the plot of normal load versus recorded shear strength through a linear regression could result in a straight line with the slope of $\tan \varphi$ and vertical intercept of $c$. In Eq. (2), $\tan \varphi$ and $\sigma \tan \varphi$ are the coefficient of friction angle and the shear resistance, respectively (Chaulya and Prasad 2016). The shear resistance is produced from the interfaces between sand grains on the shearing plane, and the fixed sand grains. The effect of cementation quality between sand colloids appears in the cohesion parameter, and it arises from internal forces holding sand grains (Chaulya and Prasad 2016).

\section{Flow erosion resistance}

The bond strength among sand particles can be evaluated by flow erosion-resistant test (Xu et al. 2018). Many experimental studies reported a straightforward relationship between the formed crust on sand particles and the sand consolidator/stabilizer efficiency (Athukorala 2013; Gillette et al. 1982; Neuman et al. 1996). The most common method to evaluate the flow erosion resistance is by using a flow tunnel based on the weight loss of the embedded sand surface. This test could be performed at a laboratory scale with specified airflow on the fixed sand sample with different incidence angles (Zang et al. 2015). The setup generally consists of a flow producer, sand tray, flow velocity controller, and a dust accumulator (see Fig. 3).

To perform the wind tunnel test correctly, the range of wind velocity should be chosen based on practical experiences and requirements. The wind velocity in different fields ranges from 0 to $20 \mathrm{~m} / \mathrm{s}$ (Faria et al. 2011; Neuman et al. 2009). Ranges of flow velocity at the pore scale in porous media are too wide. The most common flow laws in reservoirs are described by Darcy and Forchheimer equation. Dimensionless Reynolds number $\left(N_{\mathrm{Re}}=\rho_{L} v_{L} k^{1 / 2} / \mu_{L}\right)$ range of 1-10 is the transition zone from Darcy's law to the Forchheimer equation (Ho and Webb 2006). Also, a range of Reynolds numbers from 0.1 to 75 is reported for non-Darcy flow (Dullien 2012). Usually, non-Darcy flow occurs in a gas reservoir. Hence, the upper limit of fluids velocity in porous media can be defined by Reynolds number as high as 75. An example of superficial velocity versus pressure gradient for unconsolidated sand is shown in Fig. 4.

In erosion of sandstone formation, produced water plays a very important role. It has been shown that higher water saturation in borehole cause lower cohesion force of the particles and consequently easier erosion (Wang et al. 2019b). Also, field data shows that at the water 
Fig. 3 Schematic of the wind tunnel test used to evaluate the flow erosion resistance of a sample

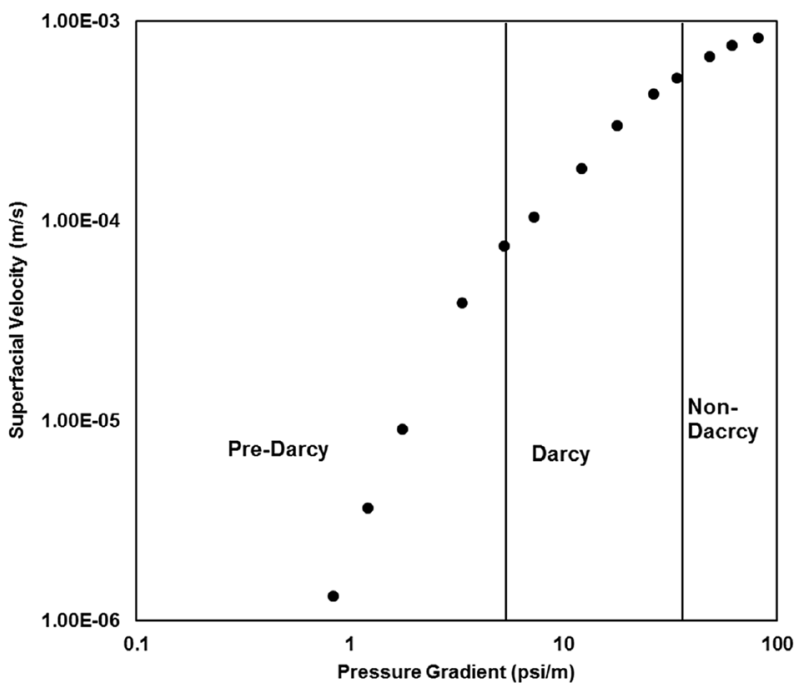

Fig. 4 Superficial velocity versus pressure gradient reported by Basak for an unconsolidated sand core with a diameter of $0.149 \mathrm{~mm}$ (Macini et al. 2011)

breakthrough time, and sand production rate can increase tenfold (Failed 2002),

\section{Other mechanical tests}

Penetration resistance and rainfall erosion resistance are two well-known tests that are employed by engineers to measure the efficiency of sand consolidator/stabilizer in desertification, dust control, etc. However, these tests are not necessary for a petroleum engineer in sand production study. Their focuses are on the surface spraying and properties of chemical consolidator/stabilizer agents on the surface, while the pore size effect is ignored. In Table 4, the experimental tests of the reviewed articles which had been conducted to evaluate the efficiency of consolidators/stabilizers are listed.

\section{Proposed test}

\section{Wettability variation}

In the recent decade, it was demonstrated that some chemical agents could change the rock surface wettability (Dehghan Monfared et al. 2016; Azadi Tabar et al. 2019a; Arabloo et al. 2016; Erfani Gahrooei et al. 2017; Gahrooei and Ghazanfari 2017a, b; Maghzi et al. 2011,2012; Mohammadi et al. 2012; Gahrooei et al. 2017; Sadatshojaei et al. 2016; Roustaei et al. 2013). Usually, chemical consolidator/stabilizer agents could be adsorbed or glued onto the surface of reservoir rock, and such phenomena might change the inherent wettability of the treated region (around the wellbore) (ElHoshoudy et al. 2017; Failed 2017). For example, in a sandstone type of gas condensate reservoir that suffers from sand production (Isehunwa et al. 2017; Tananykhin et al. 2018), to prevent liquid blockage because of pressure drop, the wettability of the region around wellbore could be modified to liquid repellence (Azadi Tabar et al. 2020; Shayesteh et al. 2020). If a chemical consolidator/stabilizer agent, which is inherently oil-wet like resin, is used to consolidate the formation, it could cause an unwanted wettability variation of sandstone to oil-wet. Such a problem could even happen in an oil reservoir. Therefore, the effect of consolidator/stabilizer agents on not only porosity and permeability reduction but also wettability is vital. Contact angle measurement, imbibition, and relative permeability curves are the most common methods for wettability variation determination. Hence, these tests seem to be useful tests for evaluation of consolidator/stabilizer performance. The contact angle is 


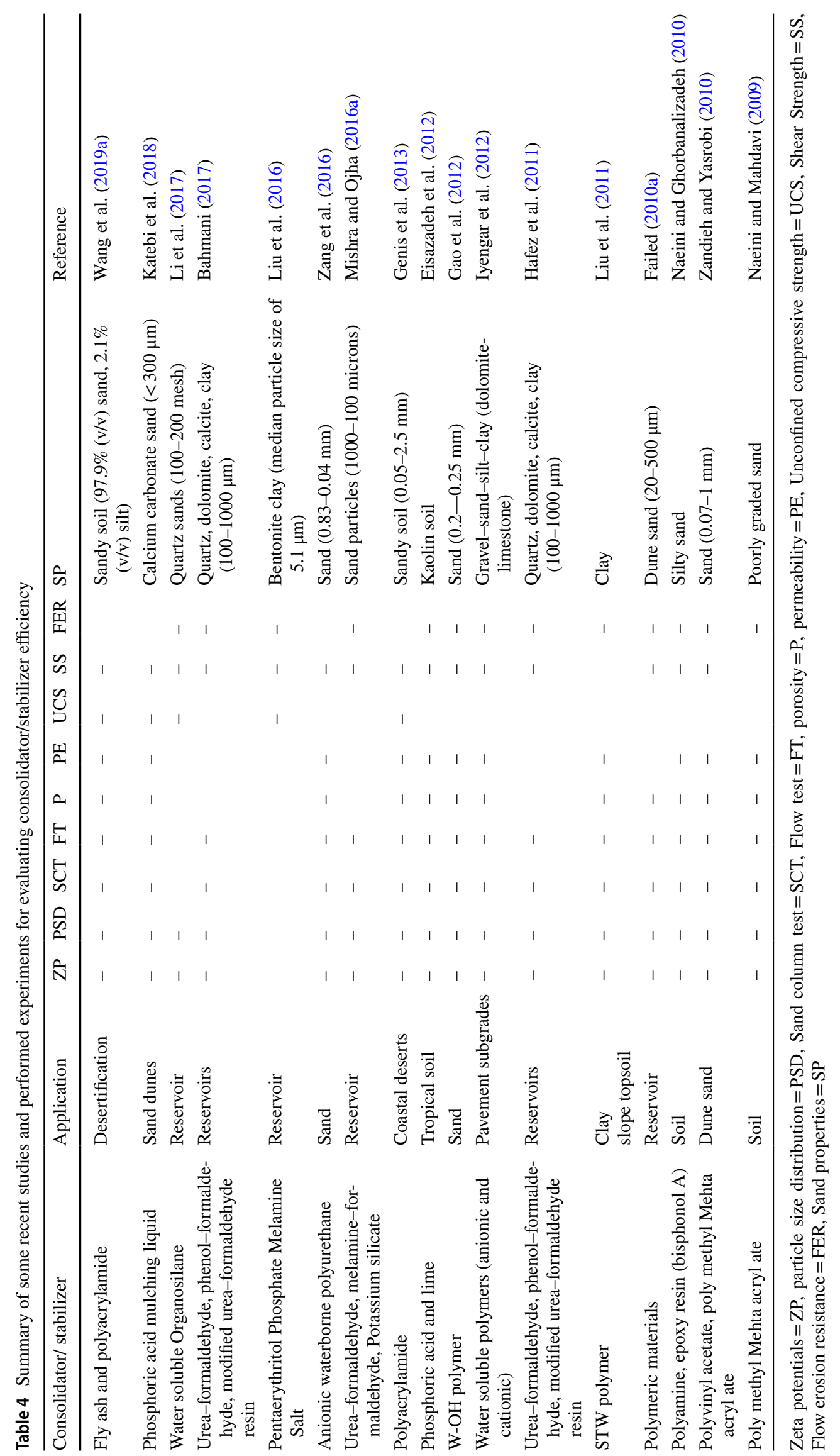


defined as the angle between a tangential to the liquid surface at the three phases contact line and the plane of the solid surface on which liquid advances or resides (Yuan and Lee 2013; Azadi Tabar et al. 2019b). A positive cosine of contact angle (measured at denser liquid) represents the denser phase wets the surface, while the lighter phase wets the surface if a negative cosine of contact angle occurs. Relative permeability $\left(k_{r r} / k\right)$ is the ratio of the effective permeability $\left(k_{r f}\right)$ to a given fluid at a specific saturation to the absolute permeability $(k)$ (Ahmed 2006a). Usually, for exact determination of the influence of an adsorbent on the wettability of porous adsorbent, the relative permeability curve of the fluids or endpoint relative permeability of fluids before and after adsorbing process is determined (Gahrooei and Ghazanfari 2017b; Aminnaji et al. 2015; Kewen and Abbas 2000). In addition, an imbibition test is applicable to evaluate the wettability variation through fluid imbibition into the porous media sample. In this test, the mass of fluid absorbed in a sample versus time is measured before and after the adsorption process. A fluid wet sample absorbs more of the fluid than one with a non-wetting nature.

\section{Modified wind tunnel}

Similar to the contact angle test, which is performed on surface and gives some insights about wettability and relative permeability of porous media, there could be a similar surface test in sand production experiments. This can be achieved by some modification on the wind tunnel test described in Sect. 3.8. For example, at different rates of fluid flow instead of just air (gas and liquid or even multiphase flow), the test can be performed for unconsolidated and chemically consolidated sand, and then results can be compared. The results of the wind tunnel test should be in agreement with the flow test that is usually performed by petroleum engineers (see Sect. 3.4).

\section{Consolidator/Stabilizer agents}

Chemical consolidation/stabilization by utilizing organic and inorganic consolidators/stabilizers have been widely used in engineering applications. Inorganic consolidator/ stabilizer agents require larger amounts and longer curing time to reach significant enhancement in consolidation/stabilization strength in comparison with organic consolidator/ stabilizer agents (Xu et al. 2018). The latter because of low cost and environmental friendly represents better performance, but usually at a temperature higher than $80^{\circ} \mathrm{C}$, it is subjected to thermal and hydraulic degradation and cannot be used (Mishra and Ojha 2015).

Inorganic consolidator/stabilizer can be classified into two categories of traditional and non-traditional consolidator/ stabilizer. Some inorganic traditional consolidator/stabilizer agents are bitumen, lime, fly ash, and cement. Several improper factors of this kind of consolidator/stabilizer are harmful effects on their work environment, occupational health problem, safety issues, toxicity, and affection on the acidity of soil (Xu et al. 2018). In some instances, the variation of $\mathrm{pH}$ may worsen or enhance the unconfined compressive strength, shear strength, durability and longevity of sample (Xu et al. 2018; Biggs and Mahony 2004). Moreover, these consolidators/stabilizers may cause a reduction in residual water saturation (Nalbantoglu and Tuncer 2001). Bitumen types of consolidator/stabilizer can prevent water infiltration. Some inorganic non-traditional consolidator/ stabilizer agents are salts (a compound which consists of calcium, magnesium, and sodium chloride) and inorganic acids (Tingle et al. 2007; Xue et al. 2018). This kind of consolidator/stabilizer, usually stabilize sand (fine) through cation exchange mechanism, and are useful for clay size particle (Tingle et al. 2007). Organic consolidator/stabilizer can be classified as lignosulfonate, organic acids, enzymes, tree resins, polymers, petroleum emulsions.

\section{Organic consolidator/stabilizer}

There is not a global definition for the organic compound. Any definition of the organic compound seems to be uncompleted, and many substances need to be excluded from this definition. However, the organic compound could be defined as a compound that contains a significant amount of carbon atoms as well as bearing carbon-carbon and carbon-hydrogen bonds (McCain 1990; Seager and Slabaugh 2013).

\section{Acid-base (lonic)}

Acid consolidators/stabilizers cause a decrement in the $\mathrm{pH}$ of pore fluid. Scholen (Scholen 1995) stated that the acid consolidator/stabilizer (sulfonated oil) through cation exchange results in flocculation of the clay. The positive charge of acids can react with negatively charged sand particles through adsorption charge neutralization. The surface charge and consequently flocculation mechanism can be investigated through the effects of $\mathrm{pH}$ on zeta potential. The acid consolidator/stabilizer mechanism suggests that these additives are more effective for colloids that their behavior is significantly affected by the electrical charges of the pore fluid and colloids. The effect of $\mathrm{pH}$ on zeta potential values of different components of sand particles is shown in Fig. 5. If one wants to consolidate/stabilize sand particles through reducing $\mathrm{pH}$, in other words adding acid consolidator/stabilizer, Fig. 5 shows that $\mathrm{CaCO}_{3}$ and dolomite can be aggregated by acid consolidator/stabilizer mechanism. Also, if aggregation occurs at |zeta potentials $\mid<10 \mathrm{mv}$ ( $\mathrm{Lu}$ and Gao 2010; Uskoković et al. 2010), acid consolidation/

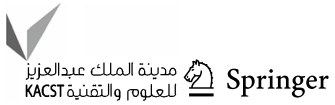




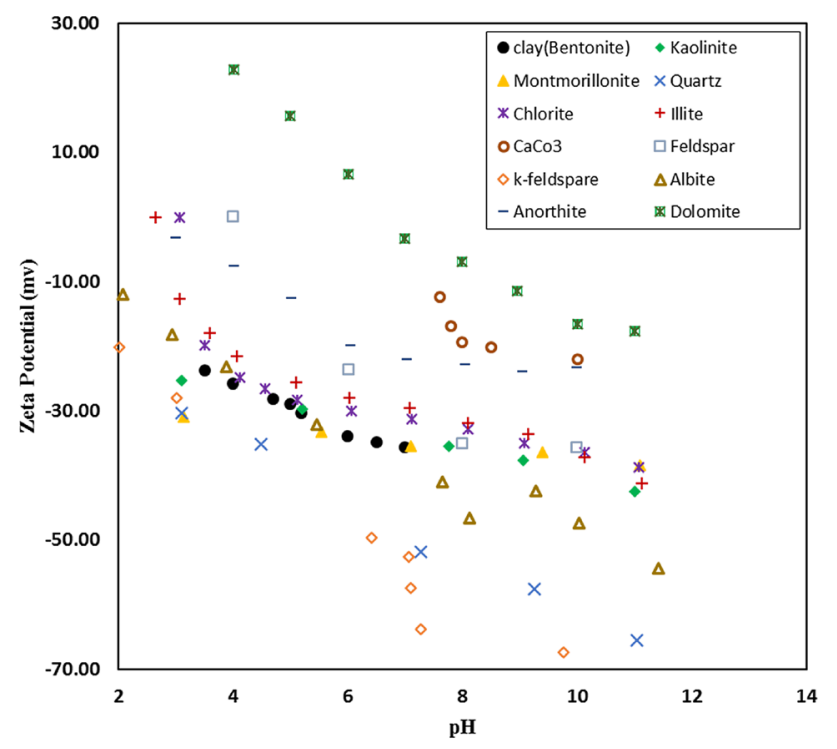

Fig. 5 Effects of $\mathrm{pH}$ on zeta potential of different components of sand particles (Liu et al. 2016; Kaya and Yukselen 2005; Hussain et al. 1996; Monfared et al. 2015; Vidyadhar et al. 2002; Malysiak et al. 2002; Abeidu and Kholeif 1976; Marouf et al. 2009)

stabilization of feldspar, chlorite, illite, and anorthite are experimentally possible, but it happens at $\mathrm{pH}<4$.

Katz et al. (2001) and Rauch et al. (1993) conducted many laboratory tests to investigate the effectiveness of ionic mechanism to consolidate/stabilize sand particles such as kaolinite, illite, and montmorillonite. They reported insignificant changes in the $d$-spacing between molecular layers, X-ray diffraction results, $\mathrm{Al} / \mathrm{Si}$ ratios, and specific surface area for very high additive quantities of acids. Moreover, the macro-characterization laboratory test such as compaction characteristics and undrained shear strength conducted by Rauch et al. (1993) on the untreated and treated sand showed insignificant, inconsistent changes in the mechanical properties of the tested sand particles. Similarly, Santoni et al. (2002), as well as Tingle and Santoni (2003), experienced almost no effects on mechanical properties when tried to consolidate/stabilize clay with acids. However, some acid consolidators/stabilizers can react with sand particles to produce an in situ component for the consolidation/stabilization of particles. Katebi et al. (2018) investigated the effect of phosphoric acid as a sand consolidator/stabilizer agent for Aragonitic (calcareous) with a particle size smaller than $300 \mu \mathrm{m}$. They showed that calcium carbonate compound of calcareous sand could react with phosphoric acid as

$\mathrm{CaCO}_{3}(\mathrm{~s})+\mathrm{H}_{3} \mathrm{PO}_{4}(\mathrm{aq})+\mathrm{H}_{2} \mathrm{O}(\mathrm{l}) \leftrightarrow \mathrm{CaHPO}_{4} \cdot 2 \mathrm{H}_{2} \mathrm{O}(\mathrm{s})+\mathrm{CO}_{2}(\mathrm{~g})$

results of this reaction are dicalcium phosphate dihydrate cement, which produces a stiff and durable crust to glue sand particles together. They reported no loss of mass in wind tunnel test after curing of soil, while before curing, $1030 \mathrm{~g}$ lost was reported. In addition, for sample with $10 \%$ phosphoric acid, they reported $\sim 400 \mathrm{kPa}$ increase in penetration resistance. The biggest disadvantages of acids stabilizer are significant curing time and their low reaction rates with sand particles. Many studies in acid consolidation/stabilization have been focused on the effects of phosphoric acid (Eisazadeh et al. 2012; Demirel et al. 1961; Lyons and McEwan 1962; Medina and Guida 1995), sulfuric acid (Rauch et al. 1993; Katz et al. 2001) and D-limonene (citrus stripper oil) (Rauch et al. 1993; Katz et al. 2001) on sand consolidation/ stabilization.

\section{Enzymes}

Enzymes are a macromolecular organic catalyzer of chemical reactions, and their consolidation/stabilization mechanism works through the attraction of larger organic molecules as well as negative surface charge. Enzymes diffusion to the reaction site to catalyze the reaction is usually a timeconsuming process. The same as acids, experimental reports have shown a minor effect on the variation of sand properties. Micro- (X-ray diffraction) and macro- (unconfined compressive strength) scale studies of Rauch et al. (Rauch et al. 1993) and Tingle and Santoni (Tingle and Santoni 2003), respectively, showed insignificant variation in treated sand properties. Also, Santoni et al. (Santoni et al. 2002) treated granular sands with four different enzyme additives, and after 28 days of treatment, observed no substantial variation in treated sand properties.

\section{Lignosulfonate}

The word origin of lignin is from the Latin word lignum which means wood (Lebo et al. 2002). Lignosulfonate (sulfonated lignin) is an anionic polyelectrolyte natural polymeric consolidator/stabilizer soluble in water at any $\mathrm{pH}$ (Indraratna et al. 2014) with a molar mass ranging from 4.6 to $398 \mathrm{~kg}$ (Karol 2003). Its products (sodium, calcium, and ammonium lignosulfonates) are produced from the lignin that binds cellulose fibers together. Lignosulfonates are environmentally friendly, non-toxic, low-cost, and noncorrosive. Annually, the world production of lignosulfonate is more than 50 million tones (Xiao et al. 2001). The literature considers two consolidation/stabilization mechanisms for lignosulfonate. The one mechanism is cementing sand by mechanical bonds between sand particles (Tingle et al. 2007). Another mechanism is through reaction and cation exchange capacity in which it can adhere to sand particles (Tingle et al. 2007). The zeta potential of sodium lignosulfonate and calcium lignosulfonate solutions is negative (Yang et al. 2007b; Ouyang et al. 2006). 
Santoni et al. (2002) stated that treating silty-sand with lignosulfonate improves structural strength. It causes a weaker structure strength enhancement than polymer consolidator/stabilizer, but stronger than other organic consolidators/stabilizers. Also, through conducting an unconfined compressive strength test, Santoni et al. (2005) showed that wet strength of silty-sand after 7 days of curing in lignosulfonate was increased. Maximum efficiency of lignosulfonate treated materials in conducted experiments (flow erosion resistance (Athukorala 2013; Vinod et al. 2010), unconfined compressive strength (Santoni et al. 2002,2005; Tingle and Santoni 2003; Chen et al. 2014), and shear strength (Athukorala 2013; Chen and Indraratna 2014)) under different curing time is reached in the range of $0-5 \mathrm{wt} \%$. Reported values for unconfined compressive strength ranges between 500 and 700 psi. Also, poor graded materials need a lower weight percent of lignosulfonate usage (Chen et al. 2014). $\mathrm{Li}$ and Song (2002) analyzed the lignosulfonate effect on the improvement of threshold velocity at which for higher velocities, sand starts to move/migrate. Their results are shown in Fig. 6, which illustrated a significant improvement in flow erosion resistance of lignosulfonate treated sand.

\section{Polymers}

Polymers are larger molecules (macromolecules) and have long chains and subunits which theoretically their diversity is endless (Veyskarami et al. 2016; Shafiei et al. 2018). Both water and oil-soluble polymers can be used in the consolidation/stabilization process. Scholen (Scholen and "Non-standard stabilizers," 1992) hypothesis that the polymers consolidate/stabilize materials through binding to the surface

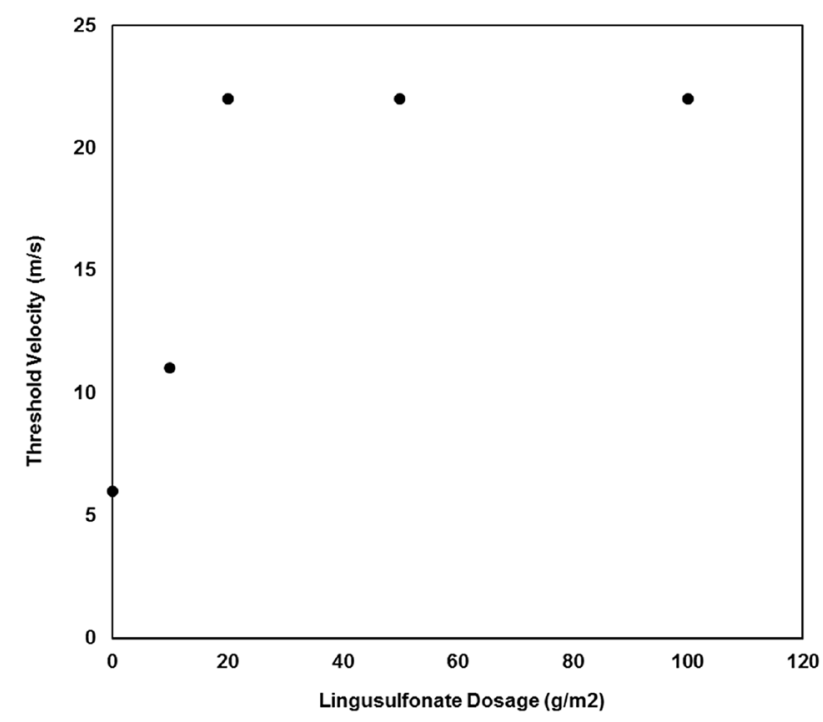

Fig. 6 Effect of lignosulfonate dosage on the threshold velocity of sand (Li and Song 2002) colloids and producing adhesive and aggregated materials. Rauch et al. (1993) stated that polymers, instead of chemically altering the clay inner layers, consolidate/stabilize through coating the surface of colloid. Their experimental results of ESEM images and BET analysis supported the consolidation/stabilization mechanism of surface coating and aggregation. Polymers with positive surface charge are reacted with a negatively charged clay surface and cause clay consolidation/stabilization (Iyengar et al. 2012). Then, polymers neutralize through electrostatic interactions with sand when the emulsion water evaporates (Iyengar et al. 2012). Also, polymers with negative surface charge lean toward to be replaced by the negative charge of sand surface (Iyengar et al. 2012). Ding et al. (2018b) study on the effect of polymers on dust control through wind tunnel test reveals that cationic polyacrylamide performed the best, and cationic guar gum outperformed anionic xanthan gum. This study also suggested one hypothesis that polymer viscosity and iconicity control enhancement efficiency. In this study, the incident angle and wind speeds were $30^{\circ}$ and $20 \mathrm{~m} / \mathrm{s}$, respectively. Gao et al. (2012) studies proved that lower incident angle causes higher wind erosion resistance of surfaces treated with polymers. In other words, if flow direction is horizontal to surface, erosion will reduce. Zang et al. ( 2016) showed that an anionic waterborne polyurethane could treat sand with zero compressive strength to achieve compressive strength larger than $1.5 \mathrm{MPa}$ in a concentration lower than $10 \% \mathrm{w}$. It has been proven that the effect of higher polymer concentration on compressive strength (Iyengar et al. 2012; Naeini and Ghorbanalizadeh 2010; Failed 2010b) and shear strength (Liu et al. 2011; Naeini and Mahdavi 2009) appears at higher curing time ( $>2$ days). Reported values for unconfined compressive strength ranges between 700 and 1100 psi.

\section{Resins}

Resins like lignosulfonates are one of the by-products of the wood industry. Resins are water repellent, insoluble in water, and highly viscous (Nic et al. 2005; Alakbari et al. 2020). Also, resin-based chemicals are not appeared to be sufficiently environmentally friendly (Kelland 2014; Failed 2015). Emulsifying agents can prevent premature coalescence of the resin (Tingle et al. 2007). Tree resin emulsions seemed to work as a coating colloids agents with a film that physically glues the colloids together (Santoni et al. 2002,2005; Tingle and Santoni 2003). Maximum efficiency of resin consolidator/stabilizer in performed experiments (unconfined compressive strength (Talaghat et al. 2009; Santoni et al. 2002,2005; Tingle and Santoni 2003), and shear strength (Aksoy and Gor 2013; Anagnostopoulos et al. 2014)) under different curing time in order to treat materials is reached in the range of $0-6 \mathrm{wt} \%$. Some 
common resin systems are based on bisphenol a-epichlorohydrin, polyester, polyepoxide, phenol-aldehyde, furan, urea-aldehyde, urethane, and glycidyl ethers. It can be mentioned that the furan resin in the presence of acid catalysts $2-3$ is self-polymerizing; hence, it does not require a curing agent (Kelland 2014). Continuous improvement of the unconfined compressive strength of sand with the increase in resin dosage is reported for a curing time of 2 days (Naeini and Ghorbanalizadeh 2010; Lahalih and Ahmed 1998; Anagnostopoulos et al. 2011; Gopal et al. 1988). Compressive strength has a straightforward relation with curing time until it reaches a peak value, then for more considerable curing time, it reaches a constant value which may be beneath peak value (Yang et al. 2007a) or equal (Anagnostopoulos et al. 2014). Aksoy et al. (Aksoy and Gor 2013) showed that for resin concentration 0, 1 , 3,5 , and $10 \mathrm{wt} \%$, at $5 \mathrm{wt} \%$ the cohesion has a maximum, while the friction angle has a minimum. Anagnostopoulos et al. (Anagnostopoulos et al. 2014) reported that the friction angle of resin-treated sand decreases between curing time of 7 days and 28 days, and after 28 days kept constant, whereas the cohesion force continuously increased. Yang et al. (2007a), for curing time of 28 days, wind speed of $12 \mathrm{~m} / \mathrm{s}$ and resin concentration ranges $\leq 3 \mathrm{wt} \%$ showed that just in long curing times the resin consolidator/stabilizer concentration could increase the flow erosion resistance. In such a curing time, higher consolidator/stabilizer concentrations caused an increase in wind erosion resistance. In the water erosion resistance experiment for (KMCO955) resin, Hsu et al. (2010) investigated the effects of resin concentration on erosion rate. There is a minimum value in erosion rate with an initial increment in resin at $5 \%$ concentration. Then, a larger increment in concentration results in no variation in erosion rate or even make the situation worsen (Hsu et al. 2010). Talaghat et al. (Talaghat et al. 2009) investigated the role of phenol resin, phenol-formaldehyde, epoxy, and furan or phenol-furfural on permeability and porosity of porous media. They utilized six types of resins, including two types of epoxy resins, three types of phenol-formaldehyde resins, and a single type of acrylic resin for testing. They resulted that only for a special kind of phenol-formaldehyde resins, the retention of porosity and permeability of samples are in a suitable range, while their unconfined compressive strength modified to $>3000$ psi. Tabbakhzadeh et al. (2020) measured permeability, porosity, compressive strength, and Young's modulus of a sandstone rock stabilized by different concentrations of epoxy and furan agents. They reported higher porosity reduction of core stabilized by epoxy (from $\sim 0.35$ to $\sim 10)$ in comparison with furan $(\sim 35$ to 25$)$. However, compressive strength of samples treated with epoxy were higher than furan (Tabbakhzadeh et al. 2020).

\section{Asphaltene}

Asphaltene emulsions are a common petroleum product utilized as sand consolidator/stabilizer agent (Tingle et al. 2007). Asphaltene is the large molecules (molecular weight 1000-4000) (Mullins and Sheu 2013), soluble in high surface tension liquids such as benzene (Mitchell and Speight 1973), and consist of hydrogen and carbon molecules with one to three nitrogen, oxygen and sulfur molecules (McCain 1990). The ring structure of asphaltene could have a nonhydrocarbon component (McCain 1990). Asphalt consolidator/stabilizer usually comprise asphalt colloids dispersed in water along with a surfactant agent that suspends the asphalt colloids. Consolidated/stabilized samples resulted from the precipitation and solidification of asphaltene caused compressive strength $>500 \mathrm{psi}$ (Mishra and Ojha 2015).

\section{Traditional inorganic consolidator/stabilizer}

Many studies focused on bitumen (Ola 1991; Batra and Arora 2016), lime (El-Rawi and Awad 1981; Wayal et al. 2012), fly ash (Ansary et al. 2007; Parker et al. 1977), and cement (Amadi and Osu 2018; Baghdadi and Rahman 1990; Hashad and El-Mashad 2014; Siddique and Rajor 2012) types consolidators/stabilizers. Bitumen is a waterproofing consolidator/stabilizer agent, viscous liquid, or even solid, black color, and soluble in carbon disulfide (Ola 1991). Batra and Arora (Aiban 1994), investigated the effect of cationic bitumen emulsion on soil through conducting the direct shear test. They reported the maximum shear strength at $6 \mathrm{w} \%$ bitumen emulsion. Similar results of sand-like particles modification by bitumen consolidator/stabilizer can be found elsewhere (Ola 1991; Udaya Sri and Kumar 2007; Verma 2015; Perika and Venkataratnam 2015). Lime is a calcium-containing mineral, soluble in water, corrosive, and hazardous (Kezdi 1979). It is derived from limestone or chalk, which are mainly composed of calcium carbonate. $\mathrm{Ca}$ and $\mathrm{O}$ are the main chemical elements of quicklime $(\mathrm{CaO})$ and hydrate lime $\left(\mathrm{Ca}(\mathrm{OH})_{2}\right)$, which are the most common lime consolidator/stabilizer (Wayal et al. 2012; Quang and Chai 2015; Makusa 2013). Cation exchange capacity is the mechanism of lime consolidation/stabilization (Makusa 2013). The presence of hydrocarbons could decrease the efficiency of lime and cement consolidator/stabilizer (Makusa 2013; Tremblay et al. 2002). Nearly, the first-born consolidator/stabilizer agent is cement. Cement is soluble in water, and its reaction is independent of sand chemical composition (Sherwood 1993). Portland, sulfate resistance, blast furnace, and high alumina are some common cement available in 
the market (Makusa 2013). $\mathrm{Ca}_{3} \mathrm{Si}, \mathrm{Ca}_{2} \mathrm{Si}$, and $\mathrm{Ca}(\mathrm{OH})_{2}$ are the main component of cement, which cause consolidation/stabilization (Al-Tabbaa and Stegemann 2005). Usually, $10 \mathrm{~W} \%$ of cement highly affect compressive strength ( $>10,000 \mathrm{psi}$ ) but significantly decrease permeability (Kenai et al. 2006). Fly ash is a major component of coal combustion by-products (62\%) composed of fine particles that flow out by flue gas in electric power facilities (Makusa 2013; Council 2006). Typically, chemical composition of different kinds of fly ash consists of $\mathrm{SiO}_{2}$, $\mathrm{Al}_{2} \mathrm{O}_{3}, \mathrm{Fe}_{2} \mathrm{O}_{3}, \mathrm{SO}_{3}$, and $\mathrm{CaO}$ (Council 2006). The fly ash mechanism of sand consolidation/stabilization is similar to cement because of pozzolanic properties (Ansary et al. 2007). Because of low binder effects, fly ashes usually are used beside activator. They are cheap, environmentfriendly, and accessible in a high amount (Makusa 2013).

\section{Nontraditional inorganic consolidator/stabilizer (salts)}

Salts compound consists of calcium, magnesium, and sodium chloride. Flocculation, hygroscopy, cation exchange, and crystallization are the probable mechanisms of salt consolidation/stabilization. Salts are corrosive and soluble in water. Study of Rushing et al. (2005) on calcium chloride consolidator/stabilizer showed a long term consolidation/stabilization ( $>90$ days) of clayey and silty. Latifi et al. (Latifi et al. 2015) microstructural analysis of strength change of clays consolidated/stabilized with $\mathrm{MgCl}_{2}$ solution showed that the $\mathrm{MgCl}_{2}$ solution improved the unconfined compressive strength of the tested soils significantly (nearly 1.8 times of compressive strength of unmodified samples). They showed the $\mathrm{MgCl}_{2}$ consolidation/stabilization happened at the primary stage of curing; hence, these materials are suitable in projects with a tight schedule. They reported that the optimum $\mathrm{MgCl}_{2}$ content for consolidation/stabilization of bentonite and kaolin is below $10 \%$. Their analysis of the direct shear strength parameters indicated a maximum of 3.25 and 1.8 times increase of the cohesion of consolidated/stabilized kaolin and bentonite, respectively, while a limited increment in the friction angles happened. Liu et al. (Liu et al. 2016) investigated and compared the effectiveness of Pentaerythritol Phosphate Melamine salt and $\mathrm{NaCl}$ for sand consolidation/stabilization through conducting different experimental tests. They showed that the salts could effectively change the zeta potentials of sand particles and help them aggregate through electrostatic interactions and hydrogen bonds. They reported the maximum performance of pentaerythritol phosphate melamine at a concentration of 0.8 wt $\%$ under $60{ }^{\circ} \mathrm{C}$ in a neutral environment.

\section{Other consolidators/stabilizers}

Through a mixture of different consolidator/stabilizer, there could be many other kinds/classifications that are recently gained attention as consolidator/stabilizer agent. Some of them are reviewed below. Mishra and Ojha (Mishra and Ojha 2016a) developed a mixed chemical comprised of organic resins and inorganic chemicals, which was successful in sand consolidation/stabilization. Two organic resins urea-formaldehyde and melamine-formaldehyde, when mixed with inorganic silicate and curing agents, in their experiments, showed maximum improvement of uniaxial compressive strength as well as a low reduction in porosity and permeability. They reported that a mixture of the utilized consolidators/stabilizers needs less amount in comparison with the individual ones. Hafez et al. (2011) through in situ precipitation of a composite calcium phosphate-polyelectrolyte salt consolidated/stabilized sand particles. Between three different polyelectrolytes of polyacrylic acid, polyallylamine hydrochloride, and polyethyleneimine, they reported that polyallylamine hydrochloride caused maximum compressive strength and a minimum reduction in permeability of treated sand. Wang et al. (2019a) conducted a field (a desert in China) experiment to investigate the wind erosion resistance of consolidated/stabilized sand by a mixture of polyacrylamide and fly ash. Their results show an increase in wind erosion resistance of desert treated by fly ash and polyacrylamide. Shang et al. (2019) showed that curing sand particle with a foam amino resin system for $12 \mathrm{~h}$ at temperature of $60{ }^{\circ} \mathrm{C}$, the compressive strength and permeability of the consolidated core fall in the range 740-900 psi and $0.92-2.7 \mu \mathrm{m}^{2}$, respectively.

Another interesting kind of stabilizers are nanoparticle that has received much attention in petroleum industry. Furthered information related to this stabilizer can be found elsewhere (Alakbari et al. 2020; Mishra and Ojha 2016b; Espin et al. 2003).

\section{Comparison of consolidators/stabilizers}

Based on five essential characteristics required for the petroleum industry, the quality of the reviewed consolidator/stabilizer agents is compared in Fig. 7. The selected characteristics are permeability and porosity maintenance, unconfined compressive strength enhancement, cost-effectiveness, environmentally friendly, and harsh condition. The quality of each characteristic was classified into three different levels; low, intermediate, and high. Qualities of the characteristics were roughly determined based on the reviewed articles. For example, the lignosulfonate is not durable in harsh conditions (low quality), but it is cost-effective and environmentally friendly (high quality). Also, the lignosulfonate has 
Fig. 7 Comparison of different kinds of chemical consolidators/ stabilizers

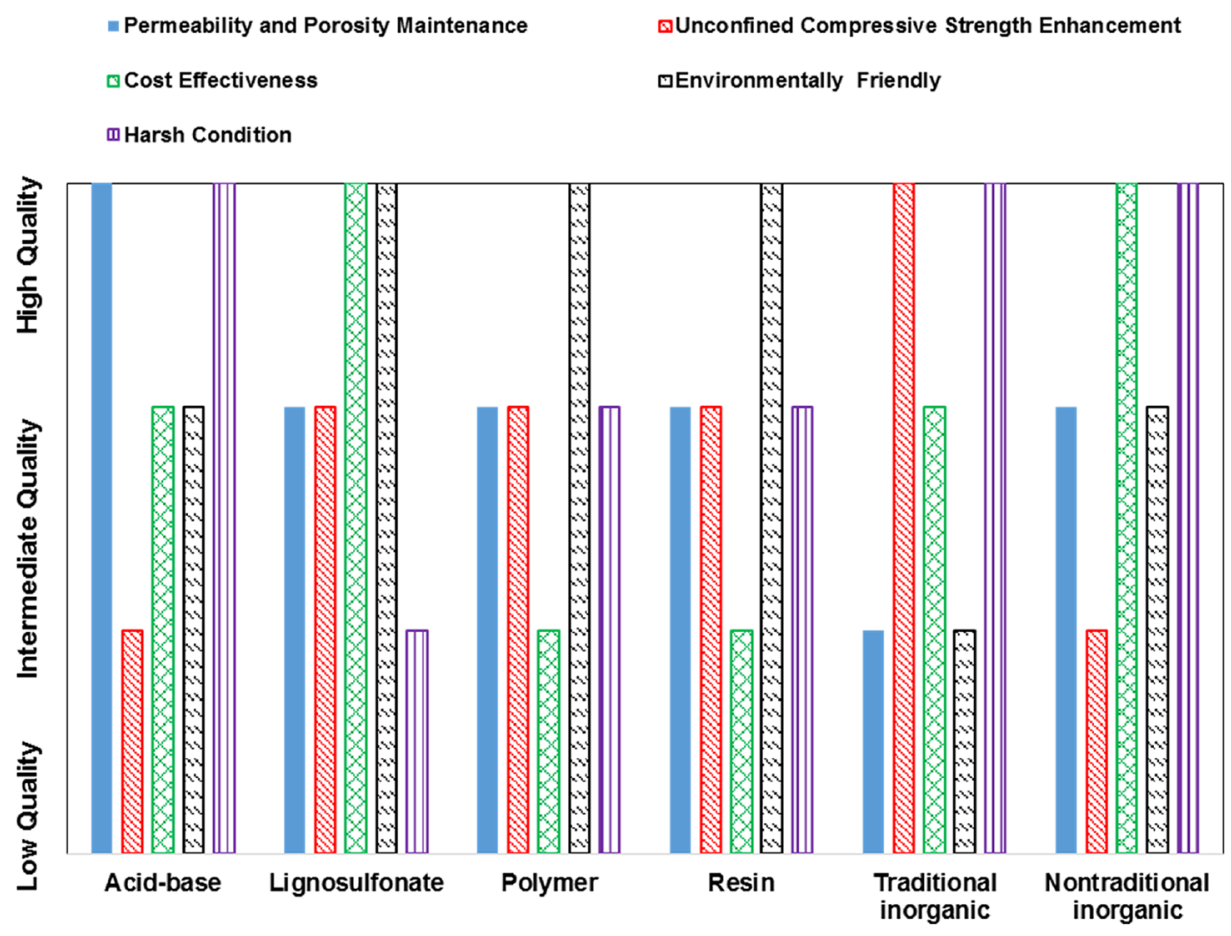

an intermediate quality in the enhancement of compressive strength as well as permeability and porosity maintenance.

\section{Future studies}

Well productivity of oil and gas reservoirs can be severely impaired by wettability variation around the wellbore. For example, in gas condensate reservoirs, many studies focused on modification of phase mobility by wettability alteration to gas-wet around wellbore (Erfani Gahrooei et al. 2017; Gahrooei and Ghazanfari 2017a, b; Gahrooei et al. 2017; Azadi Tabar et al. 2019c). Typically, these reservoirs are initially single-phase gas, but after pressure decline below the dew point pressure because of gas production, a trapped condensate liquid phase by capillary forces is formed (Aminnaji et al. 2015). Based on the wetness of the near-wellbore region, immobile condensate saturation around wellbore can reach 0.4-0.6 (Aminnaji et al. 2015). Methods exist for reducing skin factor caused by condensate saturation are classified as mechanical and chemical approaches. Some mechanical approaches are reperforating (Aminnaji et al. 2015), horizontal well, and hydraulic fracturing (Parvizi et al. 2018). Some chemical approach are near-wellbore wettability alteration (Sharifzadeh et al. 2013; Karandish et al. 2015), injection of solvent (Aminnaji et al. 2015), dry gas (Aminnaji et al. 2015), water (Failed 1992), and nitrogen (Failed 1992). As discussed in previous sections, utilizing consolidation/ stabilization agents usually cause absolute permeability reduction, but in the reviewed articles, they did not discuss effect of consolidation/stabilization agent on wettability and relative permeability of reservoir (formation). Hence, there is a need for wettability classifications of consolidation/stabilization agents. For example, which consolidation agent can be used in a sandstone gas condensate reservoir? Which consolidation/stabilization agent can be used in oil wells?

By considering the above questions, there could be more studies on multi-application chemicals, which not only consolidate/stabilize formations but also can modify productivity index by wettability alteration. Latter may even challenge the adverse effects of absolute permeability reduction by increasing the selected phase permeability.

There are significant studies on the wettability of different kinds of reservoir rocks. Table 5 summarizes the wettability of fluid-rock-fluid systems applicable in petroleum industries. For example, in a gas condensate reservoir, the contact angle of liquid (water, oil)-rock-gas systems is essential.

The wettability of some systems in Table 5 are predicted by the Zisman plot. Zisman introduced the concept of critical surface energy in which by reducing the surface tension of a drop, the contact angle of the drop on a surface decreases until it reaches zero angle (Gindl et al. 2001). Hence, because oil has lower surface tension with respect to water, then it can be concluded that the contact angle of an oil drop on surfaces of plagioclase feldspar and $\mathrm{k}$-feldspar is lower than water drop. 
Table 5 Wettability of calcite, quartz, and feldspar rocks

\begin{tabular}{|c|c|c|}
\hline Wetness & Present phase & Reference \\
\hline Neutral, $\theta=68-80^{\circ}$ & Water-calcite-air & Gahrooei and Ghazanfari (2017b) \\
\hline Extremely oil wet, $\theta=0^{\circ}$ & Kerosene-calcite-air & $\begin{array}{l}\text { Gahrooei and Ghazanfari (2017b; } \\
\text { Azadi Tabar and Ghazanfari } \\
\text { (2019) }\end{array}$ \\
\hline Water wet & Kerosene-calcite-water & Dehghan Monfared et al. (2016) \\
\hline Water wet, $\theta=29-42^{\circ}$ & Water-quartz-air & Ethington (1990) \\
\hline Oil wet, $\theta=50-55^{\circ}$ & Kerosene-quartz-air & Askvik et al. (2005) \\
\hline Water wet, $\theta=32-42^{\circ}$ & Water-quartz-kerosene & Drelich et al. (1993) \\
\hline Water wet, $\theta=29-39^{\circ}$ & Water-plagioclase feldspar-air & Askvik et al. (2005) \\
\hline Oil wet, $\theta<29^{\circ}$ & Oil-plagioclase feldspar-air & Based on the Zisman plot \\
\hline Water wet, $\theta=24-38^{\circ}$ & Water-k feldspar-air & Askvik et al. (2005) \\
\hline Oil wet, $\theta<24^{0}$ & Oil-k feldspar-air & Based on the Zisman plot \\
\hline
\end{tabular}

\section{Conclusion}

In this review article, the features of formation sand (fines) and its adverse effects on the petroleum industry were described. There is not a general standard in the petroleum industry to evaluate and compare the efficiency of chemical sand control in reducing sand production issues. Through investigating the previous studies, the wellknown experimental methods (Zeta potential, particle size distribution, sand column, flow, porosity, permeability, unconfined compressive strength, shear test, flow erosion resistance) for evaluation of consolidator/stabilizer agent and their mechanism were reported. Moreover, the wettability measurement test and wind tunnel test were proposed to be performed in future studies on sand consolidation/stabilization. A comprehensive classification and concise application of the types of consolidators/stabilizers were introduced. Based on the previous works on the application of chemical consolidation/stabilization to the sand-like particles, the applicability of the consolidators/stabilizers for control of formation sand production was investigated and compared. The modification of mechanical parameters of sand-like particles is not the same for different types of consolidators/stabilizers. Polymer, lignosulfonate, and resin consolidators/stabilizers in low concentrations showed the best performance in previous studies for sand consolidation/stabilization but are applicable in low-temperature reservoirs. Also, a mixture of different consolidator/stabilizer agents can result in a controlling improvement of structural strength as well as a low reduction in porosity and permeability.

Funding The authors declare that they have no known competing financial interests or personal relationships that could have appeared to influence the work reported in this paper
Open Access This article is licensed under a Creative Commons Attribution 4.0 International License, which permits use, sharing, adaptation, distribution and reproduction in any medium or format, as long as you give appropriate credit to the original author(s) and the source, provide a link to the Creative Commons licence, and indicate if changes were made. The images or other third party material in this article are included in the article's Creative Commons licence, unless indicated otherwise in a credit line to the material. If material is not included in the article's Creative Commons licence and your intended use is not permitted by statutory regulation or exceeds the permitted use, you will need to obtain permission directly from the copyright holder. To view a copy of this licence, visit http://creativecommons.org/licenses/by/4.0/.

\section{References}

Abeidu A, Kholeif T (1976) Modification of the anionic flotation behaviour of ilmenite, magnetite, enstatite and anorthite. J Appl Chem Biotech 26(1):719-728

Ahmed T (2006) Reservoir engineering handbook. Elsevier, Amsterdam.

Ahmed T (2006) Reservoir engineering, Handbook, 3rd edn. Houton, Texas.

Aiban SA (1994) A study of sand stabilization in eastern Saudi Arabia. Eng Geol 38(1-2):65-79

Aksoy HS, Gor M (2013) Effect of natural resin on strength parameters of sandy soil. International Journal of Environmental Science and Development 4(1):11

Alakbari FS, Mohyaldinn ME, Muhsan AS, Hasan N, Ganat T (2020) Chemical sand consolidation: from polymers to nanoparticles. Polymers 12(5): 1069

Al-Tabbaa A, Stegemann J (2005) Stabilisation/solidification treatment and remediation. In: Proceedings of the international conference. Taylor and Francis, London.

Amadi A, Osu A (2018) Effect of curing time on strength development in black cotton soil-Quarry fines composite stabilized with cement kiln dust (CKD). J King Saud Univ-Eng Sci 30(4):305-312

Aminnaji M, Fazeli H, Bahramian A, Gerami S, Ghojavand H (2015) Wettability alteration of reservoir rocks from liquid wetting to gas wetting using nanofluid. Transp Porous Media 109(1):201-216 
Anagnostopoulos C, Papaliangas T, Manolopoulou S, Dimopoulos T (2011) Physical and mechanical properties of chemically grouted sand. Tunn Undergr Space Technol 26(6):718-724

Anagnostopoulos CA, Kandiliotis P, Lola M, Karavatos S (2014) Improving properties of sand using epoxy resin and electrokinetics. Geotech Geol Eng 32(4):859-872

Ansary M, Noor M, Islam M (2007) Effect of fly ash stabilization on geotechnical properties of Chittagong coastal soil. In: Soil stress-strain behavior: Measurement, modeling and analysis. Springer, Cham, pp. 443-454.

Arabloo M, Ghazanfari MH, Rashtchian D (2016) Wettability modification, interfacial tension and adsorption characteristics of a new surfactant: Implications for enhanced oil recovery. Fuel 185:199-210

Askvik K, Høiland S, Fotland P, Barth T, Grønn T, Fadnes F (2005) Calculation of wetting angles in crude oil/water/quartz systems. J Colloid Interface Sci 287(2):657-663

ASTM D (2006) Standard test method for unconfined compressive strength of cohesive soil," ed: American Society for Testing and Materials West Conshohocken, Pa, 2006.

Athukorala R (2013) Geotechnical characteristics of an erodible soil stabilised by lignosulfonate-an analytical perspective, Doctor of Philosophy thesis, Department of Civil, Mining and Environmental Engineering.

Azadi Tabar M, Ghazanfari MH (2019) Experimental study of surfapore nanofluid effect on surface free energy of calcite rock, (in eng). Modares Mechanical Eng 1(3):709-718.

Azadi Tabar M, Ghazanfari MH, Dehghan Monfared A (2019) On the size-dependent behavior of drop contact angle in wettability alteration of reservoir rocks to preferentially gas wetting using nanofluid. J Petrol Sci Eng 178:1143-1154.

Azadi Tabar M, Barzegar F, Ghazanfari MH, Mohammadi M (2019) On the applicability range of Cassie-Baxter and Wenzel equation: a numerical study. J Brazilian Soc Mech Sci Eng 41(10):399.

Azadi Tabar M, Ghazanfari MH, Dehghan Monfared A (2019) Compare numerical modeling and improved understanding of dynamic sessile drop contact angle analysis in Liquid-Solid-Gas system. J Petrol Sci Eng, p. 106552.

Azadi Tabar M, Shafiei Y, Shayesteh M, Dehghan Monfared A, Ghazanfari MH (2020) Wettability alteration of calcite rock from gas-repellent to gas-wet using a fluorinated nanofluid: a surface analysis study. J Natural Gas Sci Eng, p. 103613.

Baghdadi Z, Rahman M (1990) The potential of cement kiln dust for the stabilization of dune sand in highway construction. Build Environ 25(4):285-289

Bahmani AR (2017) Sand production control in sandstone reservoirs using a modified urea-formaldehyde Re. Iran J Oil Gas Sci Technol 6(2):33-45

Batra SS, Arora JS (2016) Effect of cationic bitumen emulsion on shear strength parameters of soil. Int J Res Eng Technol (IJRET) 5(9).

Bazyari A, Soulgani BS, Jamialahmadi M, Dehghan Monfared A, Zeinijahromi A (2018) Performance of smart water in clay-rich sandstones: experimental and theoretical analysis. Energy Fuels 32(10):10354-10366.

Biggs A, Mahony K (2004) Is soil science relevant to road infrastructure?. In: 13th International Soil Conservation Organisation Conference, Conserving soil and water for society: Sharing solutions, Brisbane, ISCO, 2004

Boggs S (2006) Principle of sedimentology and stratigraphy: Pearson education. Upper Saddle River.

Chaulya S, Prasad G (2016) Sensing and monitoring technologies for mines and hazardous areas: monitoring and prediction technologies. Elsevier, Amsterdam.

Chen Q, Indraratna B (2014) Shear behaviour of sandy silt treated with lignosulfonate. Can Geotech J 52(8):1180-1185
Chen Q, Indraratna B, Carter J, Rujikiatkamjorn C (2014) A theoretical and experimental study on the behaviour of lignosulfonatetreated sandy silt. Comput Geotech 61:316-327

Council N. R. (2006)Managing coal combustion residues in mines. National Academies Press.

Crocker ME, Donaldson EC, Marchin LM (1983) Comparison and analysis of reservoir rocks and related clays. In: SPE Annual Technical Conference and Exhibition, 1983: Society of Petroleum Engineers.

Crundwell F (2015) The mechanism of dissolution of the feldspars: Part I. Dissolution at conditions far from equilibrium. Hydrometallurgy 151:151-162

Dandekar AY (2013) Petroleum reservoir rock and fluid properties. CRC Press, Boca Raton.

Dehghan Monfared A, Ghazanfari MH, Jamialahmadi M, Helalizadeh A (2015) Adsorption of silica nanoparticles onto calcite: Equilibrium, kinetic, thermodynamic and DLVO analysis. Chem Eng J 281:334-344.

Dehghan Monfared A, Ghazanfari MH, Jamialahmadi M, Helalizadeh A (2016) Potential application of silica nanoparticles for wettability alteration of oil-wet calcite: a mechanistic study. Energy Fuels 30(5):3947-3961.

Dehghan Monfared A, Ghazanfari MH, Kazemeini M.,Jamialahmadi M, Helalizadeh A (2018) Wettability Alteration Modeling for Oil-Wet Calcite/Silica Nanoparticle System Using Surface Forces Analysis: Contribution of DLVO versus Non-DLVO Interactions. Ind Eng Chem Res 57(43):14482-14492.

Demirel T, Davidson D, Benn C (1961) Use of phosphoric acid in soil stabilization. Highway Research Board Bulletin, no. 282.

Ding X, Xu G, Kizil M, Zhou W, Guo X (2018a) Lignosulfonate treating bauxite residue dust pollution: enhancement of mechanical properties and wind erosion behavior. Water Air Soil Pollut 229(7):214

Ding X, Xu G, Zhou W, Kuruppu M (2018) Effect of synthetic and natural polymers on reducing bauxite residue dust pollution. Environ Technol, pp. 1-10.

Drelich J, Miller JD, Hupka J (1993) The effect of drop size on contact angle over a wide range of drop volumes. J Colloid Interface Sci 155(2):379-385

Dullien FA (2012) Porous media: fluid transport and pore structure. Academic Press, New York.

Eisazadeh A, Kassim KA, Nur H (2012) Stabilization of tropical kaolin soil with phosphoric acid and lime. Nat Hazards 61(3):931-942

El-Hoshoudy A, Desouky S, Elkady M, Al-Sabagh A, Betiha M, Mahmoud S (2017) Hydrophobically associated polymers for wettability alteration and enhanced oil recovery-Article review. Egypt J Pet 26(3):757-762

El-Rawi NM, Awad AA (1981) Permeability of lime stabilized soils. Transp Eng J ASCE 107(1):25-35

Erfani Gahrooei HR, Ghazanfari MH, Karimi Malekabadi F (2017) Wettability alteration of reservoir rocks to gas wetting condition: A comparative study. Can J Chem Eng..

Espin D, Chavez JC, Ranson A (2003) Method for consolidation of sand formations using nanoparticles. Google Patents, 2003.

Ethington EF (1990) Interfacial contact angle measurements of water, mercury, and 20 organic liquids on quartz, calcite, biotite, and Ca-montmorillonite substrates. US Geological Survey 23311258,1990

Fahes MM, Firoozabadi A (2007) Wettability alteration to intermediate gas-wetting in gas-condensate reservoirs at high temperatures. SPE J 12(04):397-407

Faria R, Ferreira AD, Sismeiro JL, Mendes JC, Sousa AC (2011) Wind tunnel and computational study of the stoss slope effect on the aeolian erosion of transverse sand dunes. Aeol Res 3(3):303-314 
Feng C, Kong Y, Jiang G, Yang J, Pu C, Zhang Y (2012) Wettability modification of rock cores by fluorinated copolymer emulsion for the enhancement of gas and oil recovery. Appl Surf Sci 258(18):7075-7081

Gahrooei HE, Joonaki E, GhazanfariM, Ghanaatian S, Youzband AH (2017) Introduction of a New Hydrocarbon Based Chemical for Wettability Alteration of Reservoir Rocks to Gas Wetting Condition. In: 79th EAGE Conference and Exhibition 2017.

Gahrooei HRE, Ghazanfari MH (2017a) Toward a hydrocarbon-based chemical for wettability alteration of reservoir rocks to gas wetting condition: Implications to gas condensate reservoirs. J Mol Liq 248:100-111

Gahrooei HRE, Ghazanfari MH (2017b) Application of a water based nanofluid for wettability alteration of sandstone reservoir rocks to preferentially gas wetting condition. J Mol Liq 232:351-360

Gao W, Wu Z, Wu Z (2012) Study of mechanism of the W-OH sand fixation. J Environ Prot 3(09): 1025

Genis A, Vulfson L, Ben-Asher J (2013) Combating wind erosion of sandy soils and crop damage in the coastal deserts: Wind tunnel experiments. Aeol Res 9:69-73

Gillette DA, Adams J, Muhs D, Kihl R (1982) Threshold friction velocities and rupture moduli for crusted desert soils for the input of soil particles into the air. Journal of Geophysical Research: Oceans 87(C11):9003-9015

Gindl M, Sinn G, Gindl W, Reiterer A, Tschegg S (2001) A comparison of different methods to calculate the surface free energy of wood using contact angle measurements. Colloids Surf, A 181(1):279-287

Ghloum EF (2010) Polymer compositions for sand consolidation in oil wells. In: SPE Production and Operations Conference and Exhibition, 2010: Society of Petroleum Engineers.

Gopal R, Singh J, Das G (1988) Chemical stabilisation of sand: Part VII Natural resins as dune sand stabiliser. Def Sci J 38(2):169-175

Hafez IT, Paraskeva CA, Klepetsanis PG, Koutsoukos PG (2011) Sand consolidation with calcium phosphate-polyelectrolyte composites. J Colloid Interface Sci 363(1):145-156

Hashad A, El-Mashad M (2014) Assessment of soil mixing with cement kiln dust to reduce soil lateral pressure compared to other soil improvement methods. HBRC Journal 10(2):169-175

Hassani AH, Veyskarami M, Al-Ajmi AM, Masihi M (2017) A modified method for predicting the stresses around producing boreholes in an isotropic in-situ stress field. Int J Rock Mech Min Sci 96:85-93

Ho CK, Webb SW (2006) Gas transport in porous media. Springer, Cham.

Hsu C-L, Dai S-Y, Chiang S-W, Chan C-Y (2010) Erosion control for mudstone soil with ventilation and watertight resin. Int J Sedim Res 25(2):194-201

Hussain SA, Demirci Ş, Özbayoğlu G (1996) Zeta potential measurements on three clays from Turkey and effects of clays on coal flotation. J Colloid Interface Sci 184(2):535-541

Indraratna B, Athukorala R, Vinod J (2014) Erosion mitigation of lignosulfonate treated unstable soils. In: 7th International Congress on Environmental Geotechnics: iceg2014, 2014, Engineers Australia, p. 793.

Isehunwa S, Ogunkunle T, Onwuegbu S, Akinsete O (2017) Prediction of sand production in gas and gas condensate wells. J Petrol Gas Eng 8(4):29-35

Iyengar SR, Masad E, Rodriguez AK, Bazzi HS, Little D, Hanley HJ (2012) Pavement subgrade stabilization using polymers: characterization and performance. J Mater Civ Eng 25(4):472-483

Jin J, Wang Y, Wang K, Ren J, Bai B, Dai C (2016) The effect of fluorosurfactant-modified nano-silica on the gas-wetting alteration of sandstone in a CH 4-liquid-core system. Fuel 178:163-171

Karagüzel C, Can M, Sönmez E, Celik M (2005) Effect of electrolyte on surface free energy components of feldspar minerals using thin-layer wicking method. J Colloid Interface Sci 285(1):192-200

Karandish G, Rahimpour M, Sharifzadeh S, Dadkhah A (2015) Wettability alteration in gas-condensate carbonate reservoir using anionic fluorinated treatment. Chem Eng Res Des 93:554-564

Karol RH (2003) Chemical grouting and soil stabilization, revised and expanded. CRC Press, Boca Raton.

Katebi H, Fahmi A, Kafil HS, Bonab MH (2018) Stabilization of calcareous sand dunes using phosphoric acid mulching liquid. J Arid Environ 148:34-44

Katz LE, Rauch AF, Liljestrand HM, Harmon JS, Shaw KS, Albers H (2001) Mechanisms of soil stabilization with liquid ionic stabilizer. Transp Res Rec 1757(1):50-57

Kaya A, Yukselen Y (2005) Zeta potential of clay minerals and quartz contaminated by heavy metals. Can Geotech J 42(5):1280-1289

Kelland MA (2014) Production chemicals for the oil and gas industry. CRC Press, Boca Raton.

Kenai S, Bahar R, Benazzoug M (2006) Experimental analysis of the effect of some compaction methods on mechanical properties and durability of cement stabilized soil. J Mater Sci 41(21):6956-6964

Kewen L, Abbas F (2000) Experimental study of wettability alteration to preferential gas-wetting in porous media and its effects. SPE Reservoir Eval Eng 3(02):139-149

Kezdi A (1979) Stabilization with lime cement in geotechnical engineering, Vol. 9. Elsevier Scientific Publication Co, Amsterdam.

Khamehchi E, Reisi E (2015) Sand production prediction using ratio of shear modulus to bulk compressibility (case study). Egypt J Pet 24(2):113-118

Khamehchi E, Ameri O, Alizadeh A (2015) Choosing an optimum sand control method. Egypt J Pet 24(2):193-202

Lahalih SM, Ahmed N (1998) Effect of new soil stabilizers on the compressive strength of dune sand. Constr Build Mater 12(6-7):321-328

Lahalih S, Ghloum E (2010) Polymer compositions for sand consolidation in oil wells. In: SPE Production and Operations Conference and Exhibition, 2010: OnePetro.

Latifi N, Rashid ASA, Siddiqua S, Horpibulsuk S (2015) Microstructural analysis of strength development in low-and high swelling clays stabilized with magnesium chloride solution-a green soil stabilizer. Appl Clay Sci 118:195-206

Lebo SE, Gargulak JD, McNally TJ Lignin (2002) Encyclopedia of Polymer Science and Technology. https://doi.org/10.1002/ 0471440264

Li J, Song Z (2002) Study on lignosulfonate and its grafted polymers as sandy soil stabilizers. Chem Indus Prod 22(1):17-20

Li K, Liu Y, Zheng H, Huang G, Li G (2011) Enhanced gas-condensate production by wettability alteration to gas wetness. J Petrol Sci Eng 78(2):505-509

Li X et al (2017) Organosilane film for sand migration control based on in-situ hydrolysis and polycondensation effects. J Petrol Sci Eng 158:660-671

Liu J, Shi B, Jiang H, Huang H, Wang G, Kamai T (2011) Research on the stabilization treatment of clay slope topsoil by organic polymer soil stabilizer. Eng Geol 117(1-2):114-120

Liu J et al (2012) Effectiveness of a new organic polymer sand-fixing agent on sand fixation. Environ Earth Sci 65(3):589-595

Liu D et al (2016) Pentaerythritol phosphate melamine salt, a new aggregating reagent for oilfield chemical sand control: preparation, properties, and mechanism. Energy Fuels 30(3):2503-2513

Lu GW, Gao P (2010) Emulsions and microemulsions for topical and transdermal drug delivery. In: Handbook of non-invasive drug delivery systems. Elsevier, Amsterdam, pp 59-94. 
Lyons J, McEwan G (1962) Phosphoric acid in soil stabilization 1. Effect on engineering properties of soils. Highway Research Board Bulletin, no. 3182.

Macini P, Mesini E, Viola R (2011) Laboratory measurements of nonDarcy flow coefficients in natural and artificial unconsolidated porous media. J Petrol Sci Eng 77(3-4):365-374

Maghzi A, Mohebbi A, Kharrat R, Ghazanfari MH (2011) Pore-scale monitoring of wettability alteration by silica nanoparticles during polymer flooding to heavy oil in a five-spot glass micromodel. Transp Porous Media 87(3):653-664

Maghzi A, Mohammadi S, Ghazanfari MH, Kharrat R, Masihi M (2012) Monitoring wettability alteration by silica nanoparticles during water flooding to heavy oils in five-spot systems: A porelevel investigation. Exp Thermal Fluid Sci 40:168-176

Makusa GP (2013) Soil stabilization methods and materials in engineering practice: State of the art review. Luleå tekniska universitet.

Malysiak V, O'Connor C, Ralston J, Gerson AR, Coetzer L, Bradshaw D (2002) Pentlandite-feldspar interaction and its effect on separation by flotation. Int J Miner Process 66(1-4):89-106

Marouf R, Marouf-Khelifa K, Schott J, Khelifa A (2009) Zeta potential study of thermally treated dolomite samples in electrolyte solutions. Microporous Mesoporous Mater 122(1-3):99-104

Marfo S, Appah D, Joel, Ofori-Sarpong G (2015) Sand consolidation operations, challenges and remedy. In: SPE Nigeria Annual International Conference and Exhibition, 2015: Society of Petroleum Engineers.

McCain WD (1990) The properties of petroleum fluids. PennWell Books, Nashville.

Medina J, Guida H (1995) Stabilization of lateritic soils with phosphoric acid. Geotech Geol Eng 13(4):199-216

Meng X, Liang L, Liu B (2017) Synthesis and sand-fixing properties of cationic Poly (vinyl acetate-butyl acrylate-2-hydroxyethyl acrylate-DMC) copolymer emulsions. J Polym Environ 25(2):487-498

Mhlanga S, O'Connor C, McFadzean B (2012) A study of the relative adsorption of guar onto pure minerals. Miner Eng 36:172-178

Mishra S, Ojha K (2015) Chemical sand consolidation: an overview. J Petrol Eng Technol 5(2):21-34

Mishra S, Ojha K (2016a) Application of an improvised inorganicorganic chemical mixture to consolidate loose sand formations in oil fields. J Petrol Sci Eng 137:1-9

Mishra S, Ojha K (2016b) Nanoparticle induced chemical system for consolidating loosely bound sand formations in oil fields. J Petrol Sci Eng 147:15-23

Mitchell DL, Speight JG (1973) The solubility of asphaltenes in hydrocarbon solvents. Fuel 52(2):149-152

Mohammadi S, Maghzi A, Ghazanfari M, Masihi M, Kharrat R (2012) On the Effect of Silica Nanoparticles on Wettability Alteration during Water Flooding to Heavy Oils-A Micromodel Study. In: 4th EAGE Conference and Exhibition incorporating EUROPEC 2012.

Monfared AD, Ghazanfari M, Jamialahmadi M, Helalizadeh A (2015) Adsorption of silica nanoparticles onto calcite: equilibrium, kinetic, thermodynamic and DLVO analysis. Chem Eng J 281:334-344

Montero J et al (2018) A critical review of sand control evaluation testing for SAGD applications. In: SPE Canada Heavy Oil Technical Conference, 2018: Society of Petroleum Engineers.

Moustafa E-AA, Shedid SA (2017) Effects of magnesium and potassium sulfates on oil recovery by water flooding. Egyptian J Petrol 27(4):649-656

Mullins OC, Sheu EY (2013) Structures and dynamics of asphaltenes. Springer, Cham.
Naeini SA, Ghorbanalizadeh M (2010) Effect of wet and dry conditions on strength of silty sand soils stabilized with epoxy resin polymer. J Appl Sci (Faisalabad) 10(22):2839-2846.

Naeini S, Mahdavi A (2009) Effect of polymer on shear strength of silty sand. Electr J Geotech Eng 14:1-11

Nalbantoglu Z, Tuncer ER (2001) Compressibility and hydraulic conductivity of a chemically treated expansive clay. Can Geotech J 38(1):154-160

Neuman CM, Maxwell CD, Boulton JW (1996) Wind transport of sand surfaces crusted with photoautotrophic microorganisms. CATENA 27(3-4):229-247

Neuman CM, Boulton JW, Sanderson S (2009) Wind tunnel simulation of environmental controls on fugitive dust emissions from mine tailings. Atmos Environ 43(3):520-529

Nic M, Hovorka L, Jirat J, Kosata B, Znamenacek J (2005) IUPAC compendium of chemical terminology-the gold book. International Union of Pure and Applied Chemistry, 2005.

Ogolo NA (2013) The trapping capacity of nanofluids on migrating fines in sand. In: SPE Annual Technical Conference and Exhibition, 2013: Society of Petroleum Engineers.

Ola S (1991) Geotechnical properties and behaviour of Nigerian tar sand. Eng Geol 30(3-4):325-336

Ouyang X, Qiu X, Chen P (2006) Physicochemical characterization of calcium lignosulfonate-a potentially useful water reducer. Colloids Surf A 282:489-497

Parker DG, Thornton SI, Cheng CW (1977) Permeability of fly ash stabilized soils. In: Proceedings of the Conference on Geotechnical Practices for Disposal of Solid Waste Materials, University of Michigan, Ann Arbor, Michigan, June 13-15, 1977.

Parvizi H, Rezaei Gomari S, Nabhani F, Dehghan Monfared A (2018) Modeling the risk of commercial failure for hydraulic fracturing projects due to reservoir heterogeneity. Energies 11(1):218.

Perika P, Venkataratnam G (2015) Laboratory study on use of bitumen emulsion in gravel road. Int J Technol Res Eng 3(4).

Pettijohn F, Potter P, Siever R (1974) Sand and sandstone. Soil Sci 117(2):130

Quang ND, Chai JC (2015) Permeability of lime-and cement-treated clayey soils. Can Geotech J 52(9):1221-1227

Ranjith P, Perera M, Perera W, Wu B, Choi S (2013) Effective parameters for sand production in unconsolidated formations: an experimental study. J Petrol Sci Eng 105:34-42

Rauch AF, Harmon JS, Katz LE, Liljestrand HM (2002) Measured effects of liquid soil stabilizers on engineering properties of clay. Transp Res Rec 1787(1):33-41

Rauch AF, Katz LE, Liljestrand HM (1993) AN analysis of the mechanisms and efficacy of three liquid chemical soil stabilizers: VOLUME. Work, vol. 1, 1993.

Roustaei A, Saffarzadeh S, Mohammadi M (2013) An evaluation of modified silica nanoparticles' efficiency in enhancing oil recovery of light and intermediate oil reservoirs. Egypt J Pet 22(3):427-433

Rushing JF, Harrison JA, Tingle JS (2005) Evaluation of application methods and products for mitigating dust for lines-of-communication and base camp operations. Engineer Research and Development Center Vicksburg MS Geotechnical and ...2005.

Sadatshojaei E, Jamialahmadi M, Esmaeilzadeh F, Ghazanfari MH (2016) Effects of low-salinity water coupled with silica nanoparticles on wettability alteration of dolomite at reservoir temperature. Pet Sci Technol 34(15):1345-1351

Santoni R, Tingle J, Webster S (2002) Stabilization of silty sand with nontraditional additives. Trans Res Record J Trans Research Board 1787:61-70

Santoni R, Tingle J, Nieves M (2005) Accelerated strength improvement of silty sand with nontraditional additives. Trans Res Record J Trans Research Board 1936:34-42 
Scholen DE (1995) Stabilizer mechanisms in nonstandard stabilizers. In: Transportation research board conference proceedings, no. 6 .

Scholen DE (1992) Non-standard stabilizers. United States. Federal Highway Administration, Office of Direct Federal Programs Washington, DC

Schön JH (2015) Physical properties of rocks: Fundamentals and principles of petrophysics. Elsevier, Amsterdam.

Seager SL, Slabaugh MR (2013) Chemistry for today: General, organic, and biochemistry. Cengage Learning.

Shafiei Y, Ghazanfari MH, Seyyedsar SM (2018) A study of liquid drainage rate from foam with population balance equation: impact of bubble evolution. Colloid Polym Sci 296(6):1097-1108

Shang X, Bai Y, Wang Z, Wang Q, Dong C (2019) A novel chemicalconsolidation sand control composition: foam amino resin system. e-Polymers 19(1):1-8.

Sharifzadeh S, Hassanajili S, Rahimpour M (2013) Wettability alteration of gas condensate reservoir rocks to gas wetness by sol-gel process using fluoroalkylsilane. J Appl Polym Sci 128(6):4077-4085

Shayesteh M, Tabar MA, Shafiei Y, Fakhroueian Z, Ghazanfari MH (2021) On the adsorption behavior of a fluorochemical onto carbonate rock with the application of wettability alteration to a gas wetting condition. J Molecular Liquids 326:115031-115031. https://doi.org/10.1016/j.molliq.2020.115031

Sherwood P (1993) Soil stabilization with cement and lime, Her Majesty Stationary Office

Shulga G, Rekner F, Varslavan J (2001) SW-soil and water: ligninbased interpolymer complexes as a novel adhesive for protection against erosion of sandy soil. J Agric Eng Res 78(3):309-316

Siddique R, Rajor A (2012) Use of cement kiln dust in cement concrete and its leachate characteristics. Resour Conserv Recycl 61:59-68

Siregar S, Hagoort J, Ronde H (1992) Nitrogen injection vs. gas cycling in rich retrograde condensate-gas reservoirs. In: International meeting on petroleum engineering, 1992: Society of Petroleum Engineers.

Sivakugan N, Arulrajah A, Bo MW (2011) Laboratory testing of soils, rocks, and aggregates. J Ross Publishing.

Tabbakhzadeh MN, Esmaeilzadeh F, Zabihi R, Mowla D (2020) Experimental study of chemical sand consolidation using epoxy and furan resins for oil wells: Experimental design models. Int J Rock Mech Mining Sci 135:104486.

Talaghat M, Esmaeilzadeh F, Mowla D (2009) Sand production control by chemical consolidation. J Petrol Sci Eng 67(1-2):34-40

Tananykhin D, Tcvetkov P, Kamoza V (2018) Analysis and recommendations of sand consolidation methods to limit sand production in gas wells. J Phys Conf Ser 1072(1):012022.

Tang G-Q, Firoozabadi A (2003) Wettability alteration to intermediate gas-wetting in porous media at elevated temperatures. Transp Porous Media 52(2):185-211

Tiab D, Donaldson EC (2015) Petrophysics: theory and practice of measuring reservoir rock and fluid transport properties. Gulf Professional Publishing, Texas.

Tingle J, Santoni R (2003) Stabilization of clay soils with nontraditional additives. Trans Res Record J Transp Res Board 1819:72-84

Tingle J, Newman J, Larson S, Weiss C, Rushing J (2007) Stabilization mechanisms of nontraditional additives. Trans Res Record J Transp Res Board 1989:59-67

Tremblay H, Duchesne J, Locat J, Leroueil S (2002) Influence of the nature of organic compounds on fine soil stabilization with cement. Can Geotech J 39(3):535-546

Udaya Sri M, Kumar PMSS (2007) An Experimental Study on Laterite Soil Stabilization Using Bitumen Emulsion. Int J Innovative Res Sci Eng Techno, pp. 2953-2971.
Uskoković V, Castiglione Z, Cubas P, Zhu L, Li W, Habelitz S (2010) Zeta-potential and particle size analysis of human amelogenins. J Dent Res 89(2):149-153

Verma SK (2015) A laboratory study on use of bitumen emulsion in black soil. Int Res J Eng Technol 2(6):548-553

Veyskarami M, Ghazanfari MH (2018) Synergistic effect of like and opposite charged nanoparticle and surfactant on foam stability and mobility in the absence and presence of hydrocarbon: acomparative study. J Petrol Sci Eng 166:433-444

Veyskarami M, Hassani AH, Ghazanfari MH (2016) Modeling of nonDarcy flow through anisotropic porous media: Role of pore space profiles. Chem Eng Sci 151:93-104

Veyskarami M, Hassani AH, Ghazanfari MH (2017) A new insight into onset of inertial flow in porous media using network modeling with converging/diverging pores. Computational Geosci, pp. $1-18$.

Vidyadhar A (2001) Flotation of silicate minerals: physico-chemical studies in the presence of alkylamines and mixed (cationic/anionic/non-ionic) collectors. Doctoral Thesis, Lulea University of Technology, Lulea, Sweden.

Vidyadhar A, Rao KH, Forssberg K (2002) Adsorption of n-tallow 1, 3 -propanediamine-dioleate collector on albite and quartz minerals, and selective flotation of albite from greek stefania feldspar ore. J Colloid Interface Sci 248(1):19-29

Vinod JS, Indraratna B, Al Mahamud MA (2010) Stabilisation of an erodible soil using a chemical admixture. In: Proceedings of the Institution of Civil Engineers, 163:43-51. https://doi.org/10. 1680/grim.2010.163.1.43

Wang W et al (2018) Developing effective separation of Feldspar and Quartz while recycling tailwater by HF pretreatment. Minerals 8(4): 149

Wang Y, Yang K, Tang Z (2019a) In situ effect of combined utilization of fly ash and polyacrylamide on sand stabilization in North China. CATENA 172:170-178

Wang H, Gala DP, Sharma MM (2019b) Effect of fluid type and multiphase flow on sand production in oil and gas wells. SPE J 24(02):733-743

Wayal A, Ameta N, Purohit D (2012) Dune sand stabilization using bentonite and lime. J Eng Res Stud 3(1):58-60

Willson S, Moschovidis Z, Cameron J, Palmer I (2002) New model for predicting the rate of sand production. In: SPE/ISRM Rock Mechanics Conference, 2002: Society of Petroleum Engineers.

Xiao B, Sun X, Sun R (2001) The chemical modification of lignins with succinic anhydride in aqueous systems. Polym Degrad Stab 71(2):223-231

Xu G, Ding X, Kuruppu M, Zhou W, Biswas W (2018) Research and application of non-traditional chemical stabilizers on bauxite residue (red sand) dust control, a review. Sci Total Environ 616:1552-1565

Xue S, Li M, Jiang J, Millar GJ, Li G, Kong X (2018) Phosphogypsum stabilization of bauxite residue: Conversion of its alkaline characteristics. J Environ Sci 77:1-10

Yang J, Wang F, Fang L, Tan T (2007a) Synthesis, characterization and application of a novel chemical sand-fixing agent-poly (aspartic acid) and its composites. Environ Pollut 149(1):125-130

Yang D, Qiu X, Zhou M, Lou H (2007b) Properties of sodium lignosulfonate as dispersant of coal water slurry. Energy Convers Manage 48(9):2433-2438

Yuan Y, Lee TR (2013) Contact angle and wetting properties. In: Surface science techniques. Springer, Heidelberg, pp 3-34.

Yukselen-Aksoy Y, Kaya A (2011) A study of factors affecting on the zeta potential of kaolinite and quartz powder. Environ Earth Sci 62(4):697-705

Zandieh AR, Yasrobi SS (2010) Retracted article: study of factors affecting the compressive strength of sandy soil stabilized with polymer. Geotech Geol Eng 28(2):139-145

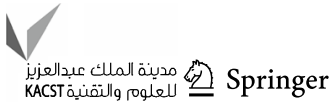


Zang Y-X, Gong W, Xie H, Liu B-L, Chen H-L (2015) Chemical sand stabilization: a review of material, mechanism, and problems. Environ Technol Rev 4(1):119-132

Zang Y, Gong W, Xie H, Du Z, Liu B, Chen H (2016) Evaluation and mechanism of anionic waterborne polyurethane dispersion for chemical sand stabilisation. Plast Rubber Compos 45(6):270-276

Zhou S, Sun F (2016) Sand production management for unconsolidated sandstone reservoirs. Wiley, New York.
Publisher's Note Springer Nature remains neutral with regard to jurisdictional claims in published maps and institutional affiliations. 